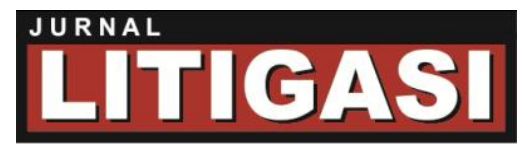

Available online at: http://ejournal.unpas.ac.id/index.php/litigasi

Litigasi, Vol. 16(1), 2015, 2658-2740

DOI: http://dx.doi.org/10.23969/litigasi.v16i1.51

\title{
MENDOBRAK KELEMAHAN LITIGASI KONVENSIONAL MELALUI MODEL ADVOKASI MANDIRI DALAM RANGKA PEMBAHARUAN PROSES PERADILAN
}

\author{
Rd.Dewi Asri Yustia \\ Dosen Fakultas Hukum Universitas Pasundan, Jl. Lengkong Besar No. 68 Bandung 40261, Telp: 022 - \\ 4262226, Fax: 022-4217340, Hp: 0817213197, E-mail: asriyustia@yahoo.co.id
}

Tuti Rastuti

Dosen Fakultas Hukum Universitas Pasundan, Jl. Lengkong Besar No. 68 Bandung 40261, Telp: 022 4262226, Fax: 022-4217340, Hp: 0818647356,E-mail: rush_2 t@yahoo.com

Utari Dewi Fatimah

Dosen Fakultas Hukum Universitas Pasundan, Jl. Lengkong Besar No. 68 Bandung 40261, Telp: 022 4262226, Fax: 022-4217340, Hp: 08157111742 ,E-mail: uteri_df@yahoo.com

\begin{abstract}
ABSTRAK
Di Indonesia, berbagai peraturan perundang-undangan telah diberlakukan untuk melindungi kaum perempuan. Bahkan, telah meratifikasi Convention on The Elimination of All Forms of Discrimination Against Women melalui Undang-Undang No. 7 Tahun 1984. Namun faktanya diskriminasi, dominasi, dan kekerasan terhadap perempuan semakin meningkat. Hal ini dilatarbelakangi ditemukannya data awal bahwa di lembaga pemasyarakatan perempuan kasus-kasus yang menimpa perempuan pelaku tindak pidana dominan bersumber dari KDRT. Penelitian ini menggunakan metode yuridis normatif dengan didukung metode yuridis empiris, melalui pendekatan multidisiplin yaitu pendekatan dari aspek hukum perdata dan hukum pidana serta hukum acara. Data yang diperoleh kemudian dianalisis secara yuridis kualitatif. Hasil penelitian menunjukan bahwa, model litigasi konvensional, mengarahkan pada seluruh proses hukum yang akan dilalui diserahkan seluruhnya kepada penasihat hukum. Model litigasi ini belum memberikan pengetahuan, pemahaman dan kesadaran hukum terhadap perempuan pelaku tindak pidana (korban termarginalkan). Hasil penelitian ini merekomendasikan perlunya model litigasi mandiri. Model ini diharapkan mampu mengakomodasi kebutuhan berlitigasi dari perempuan pelaku tindak pidana, sehingga dapat mengadvokasi dirinya sendiri pada saat menghadapi proses beracara. Selain itu, diharapkan model advokasi mandiri ini dapat dijadikan alternatif baru di dalam proses peradilan, dan dapat dijadikan alasan pertimbangan untuk dilakukannya upaya pembaharuan proses peradilan.
\end{abstract}

Kata Kunci : Pemberdayaan, Perempuan, Advokasi Mandiri, Pembaharuan.

Copyright (C) 2015, LITIGASI, p-ISSN: 0853-7100; e-ISSN: 2442-2274 
Available online at: http://ejournal.unpas.ac.id/index.php/litigasi

Litigasi, Vol. 16(1), 2015, 2658-2740

DOI: http://dx.doi.org/10.23969/litigasi.v16i1.51

\begin{abstract}
In Indonesia, various legislations have been enacted to protect women. In fact, the Convention on the Elimination of All Forms of Discrimination Against Women has been ratified through Act No. 7 Year 1984. But numbers of discrimination, domination, and violence against women is increasing. This is motivated finding of preliminary data at the penitentiary that women cases that affect women perpetrators of criminal acts predominantly sourced from domestic violence. This study uses normative juridical methods empirically supported, through a multidisciplinary approach is the approach of the legal aspects of civil and criminal law and procedural law. The data obtained and analyzed by juridical qualitatively. The results showed that, the model of conventional litigation, directs the entire process of the law to be passed by left entirely to legal counsel. Model of this litigation has not provided the knowledge, understanding and awareness of the law against female perpetrators (victims marginalized). Results of this study recommend a model of independent litigation. This model is expected to accommodate the litigation needs of female perpetrators of criminal acts, so that they can advocate for themselves in the face of the proceedings. In addition, the model is expected to have an independent advocate can be a new alternative in the judicial process, and can be used as a reason for consideration for renewal effort does justice process.
\end{abstract}

Keywords: Empowerment, Women, Self Advocacy, Renewal.

Copyright @ 2015, LITIGASI, p-ISSN: 0853-7100; e-ISSN: 2442-2274 
Available online at: http://ejournal.unpas.ac.id/index.php/litigasi

Litigasi, Vol. 16(1), 2015, 2658-2740

DOI: http://dx.doi.org/10.23969/litigasi.v16i1.51

\section{PENDAHULUAN}

Di Indonesia terdapat berbagai Peraturan Perundang-Undangan yang terkait dengan Perlindungan Hukum bagi Perempuan. UndangUndang No. 1 Tahun 1974 Tentang Perkawinan dianggap sebagai salah satu bentuk peraturan hukum awal yang masuk kualifikasi perlindungan terhadap perempuan. Diratifikasinya Convention on The Elimination of All Forms of Discrimination Against Women (CEDAW) melalui Undang-Undang No. 7 Tahun 1984 tentang Pengesahan Konvensi Mengenai Segala Bentuk Diskriminasi Terhadap Wanita menjadi awal pembaharuan sistem perlindungan terhadap perempuan. Inpres No. 9 Tahun 2000 tentang Pengarusutamaan Gender (gender streaming), dan Undang-Undang No. 23 Tahun 2004 Tentang Penghapusan Kekerasan dalam Rumah Tangga. Beberapa hal penting yang diatur oleh UndangUndang ini antara lain, pendefinisian tindak kekerasan, pengertian rumah tangga, pengaturan berbagai tindak kekerasan/kejahatan yang termasuk dalam lingkup rumah tangga, mengatur sanksi bagi pelaku serta mengatur hak-hak korban. Pada implementasinya, Undang-Undang ini belum mampu menekan angka kekerasan dalam rumah tangga (Romany Sihite, 2007). Perlindungan Hukum tersebut diberikan tak terkecuali terhadap seluruh perempuan. Termasuk didalamnya perempuan yang terikat perkawinan atau tidak, bebas atau terikat status hukum, dan tidak membedakan status sosial. Namun faktanya, banyak perempuan yang menghadapi persoalan hukum termarginalkan. Menurut data 
Available online at: http://ejournal.unpas.ac.id/index.php/litigasi

Litigasi, Vol. 16(1), 2015, 2658-2740

DOI: http://dx.doi.org/10.23969/litigasi.v16i1.51

(https://www.jurnalperempuan.org, 2014) Perilaku kekerasan dalam bentuk khusus, yaitu kekerasan terhadap perempuan (disingkat KTP) di Indonesia dari tahun ke tahun meningkat drastis. Jika tahun 2012 ada lebih 600 kasus, maka tahun 2013 tercatat 992 kasus, yang dominan adalah kasus KDRT sebanyak 372 kasus dan kasus kekerasan dalam pacaran berjumlah 59 kasus. Konsentrasi penelitian difokuskan terhadap perempuan pelaku tindak pidana dalam kasus hukum kekerasan Dalam Rumah Tangga (KDRT), hal ini dilatar belakangi ditemukannya data awal bahwa di lembaga pemasyarakatan perempuan apabila ditelisik lebih mendalam kasus-kasus yang menimpa pelaku tindak pidana dominan bersumber dari KDRT. Selain itu, dalam Kasus KDRT tersebut ditemukan fakta yang semula perempuan menjadi korban KDRT, berubah menjadi pelaku KDRT karena dampak dari kekuasaan laki-laki sebagai suami. Banyak kasus yang terjadi berawal dari keinginan suami melakukan poligami, yang berakhir pada pemutar balikan kasus yang seharusnya perempuan sebagai korban tetapi beralih sebagai pelaku tindak pidana, sehingga persoalan KDRT tersebut yang seharusnya masuk dalam ranah hukum perkawinan dan diselesaikan secara keperdataan, namun diproses melalui tuntutan yang didasarkan secara hukum pidana. Berdasarkan fakta hukum di atas, ternyata perempuan (yang berstatus istri) banyak yang tidak memiliki pemahaman tentang kedudukan hukum dalam perkawinan, sehingga sering terjadi perempuan menjadi objek persoalan (objek hakim, objek suami, objek polisi, atau objek ekspoloitasi penegakan hukum), dikarenakan tidak 
Available online at: http://ejournal.unpas.ac.id/index.php/litigasi

Litigasi, Vol. 16(1), 2015, 2658-2740

DOI: http://dx.doi.org/10.23969/litigasi.v16i1.51

mengerti kedudukan hukum secara keperdataan, maka juga menjadi objek penegakan hukum pidana. Dilatarbelakangi posisi demikian, maka perempuan menjadi termarginalkan. Tentu saja penyelesaian kasus perdata yang diselesaikan secara pidana dirasakan tidak adil dan mengurangi bahkan menghilangkan hak-hak perempuan. Penegak hukum dalam hal ini, telah salah menerapkan hukum dan memberikan putusan yang tidak adil, dan menyalahgunakan kewenangan. Termarginalkannya perlindungan hukum terhadap perempuan terjadi pula dalam proses litigasi.

Proses litigasi yang selama ini dilakukan, seluruh proses hukum yang akan dilalui diserahkan seluruhnya kepada penasihat hukum. Model litigasi selama ini belum memberikan kesadaran terhadap perempuan pelaku tindak pidana (korban termarginalkan). Nasib korban seluruhnya tergantung pada penasihat hukum. Pengetahuan terhadap hak-hak korban sebagai subjek hukum tidak ditumbuhkan, karena tidak diberikan pemahaman dan kesadaran menggunakan hak-haknya.

Urgensi dari penelitian ini dapat mendobrak model litigasi yang dilakukan di dalam sistem peradilan di Indonesia (model peradilan konvensional) yang mendominasi dan kurang memberikan ruang gerak bagi kaum perempuan, juga tidak memberikan keleluasaan untuk mengapresiasikan hak-hak yang terkait dengan perlindungan hukumnya. Model litigasi yang konvesional telah menimbulkan kesenjangan dan ketimpangan, sebab subjek (perempuan pelaku tindak pidana) yang sedang menghadapi proses litigasi yang selama ini dilakukan, belum

Copyright $\odot$ 2015, LITIGASI, p-ISSN: 0853-7100; e-ISSN: 2442-2274 
memperoleh kesadaran akan hak-hak hukumnya. Seluruh proses hukum yang dilaluinya diserahkan seluruhnya kepada penasihat hukum. Nasib korban seluruhnya tergantung pada penasihat hukum. Pengetahuan terhadap hak-hak korban sebagai subjek hukum tidak ditumbuhkan, karena tidak diberikan pemahaman dan kesadaran menggunakan hak-haknya. Melalui penelitian ini akan dibuat kontruksi model litigasi mandiri sebagai alternatif terhadap perempuan pelaku tindak pidana dengan konsentrasi pada kasus kekerasan dalam rumah tangga, dengan cara mendampingi perempuan sebagai pelaku selama menjalani proses hukum, tetapi tidak secara litigasi (tidak mendampingi di pengadilan layaknya penasehat hukum) melainkan memberikan pengetahuan hukum secara jelas terkait dengan persoalan hukumnya, sehingga diharapkan akan menumbuh kembangkan kesadaran hukum terhadap perempuan tindak pidana yang termarginalkan dalam kasus kekerasan dalam rumah tangga, dan diharapkan dari pendampingan tersebut perempuan pelaku tindak pidana dapat menghadapi sendiri proses hukum tersebut dengan berbekal ilmu hukum yang telah dipahaminya. Dengan model pendampingan ini, akan memberikan alternatif penyelesaian perkara hukum bagi perempuan pelaku tindak pidana, apakah akan menggunakan proses litigasi yang selama ini berjalan (konvensional) ataukah akan menggunakan proses pendampingan, sehingga pelaku akan menghadapi sendiri proses hukum dengan berbekal ilmu dan pengetahuan yang diperoleh dalam proses pendampingan. 
Available online at: http://ejournal.unpas.ac.id/index.php/litigasi

Litigasi, Vol. 16(1), 2015, 2658-2740

DOI: http://dx.doi.org/10.23969/litigasi.v16i1.51

Berdasarkan latar belakang yang telah diuraikan maka, penelitian tentang pemberdayaan perempuan pelaku tindak pidana dalam kasus kekerasan rumah tangga melalui model advokasi mandiri perlu dilakukan. Ruang lingkup permasalahan meliputi: Bagaimana pemahaman perempuan pelaku tindak pidana tentang hak-hak perempuan dalam ruang lingkup hukum pidana dan hukum perdata dalam proses hukum dan kasus yang dihadapinya, dan bagaimana memberdayakan perempuan pelaku tindak pidana KDRT terhadap hak-haknya, kedudukan hukumnya dalam proses hukum yang sedang dan akan dilaluinya? Proses pendampingan melalui cara litigasi konvensional yang sudah berjalan faktanya banyak memiliki kelemahan, dan sering tidak dipergunakan oleh perempuan pelaku tindak pidana kasus KDRT. Apakah alternatif pendampingan bagi perempuan pelaku tindak pidana kekerasan dalam rumah tangga, dari model advokasi konvensional yang sekarang berjalan berdasarkan sistem hukum acara yang berlaku di Indonesia, baik hukum acara pidana maupun hukum acara perdata, dapat berubah menjadi model advokasi mandiri sebagai bagian dari pembaharuan proses peradilan di Indonesia?

\section{METODE PENELITIAN}

Penelitian ini merupakan penelitian yang menggunakan metode yuridis normatif dengan didukung metode yuridis empiris, dengan pendekatan multidisiplin, meliputi hukum perdata dan hukum pidana serta hukum acara, dan

Copyright @ 9 2015, LITIGASI, p-ISSN: 0853-7100; e-ISSN: 2442-2274 
Available online at: http://ejournal.unpas.ac.id/index.php/litigasi

Litigasi, Vol. 16(1), 2015, 2658-2740

DOI: http://dx.doi.org/10.23969/litigasi.v16i1.51

dianalisis secara yuridis kualitatif, yaitu dengan mengkaji hukum yang berlaku di Indonesia dalam peraturan perundang undangan dikaitkan persoalan perlindungan hukum terhadap perempuan pelaku tindak pidana pada kasus KDRT dalam sistem peradilan di Indonesia. Data yang diperoleh dari hasil penelitian baik data primer maupun data sekunder akan diolah dengan menggunakan metode yuridis kualitatif. Alasan Pemilihan Metode Pendekatan, Penggunaan pendekatan tersebut didasarkan pada pemahaman bahwa pengkajian terhadap kasus pidana khususnya terhadap kasus kekerasan dalam rumah tangga tidak hanya cukup menggunakan pendekatan satu aspek hukum saja yaitu hukum pidana dan hukum acara pidana (pendekatan normatif), tetapi juga memerlukan pendekatan terhadap aspek hukum lainnya, yaitu aspek hukum perdata, aspek hukum perkawinan, dan aspek hukum acara. Selain itu, juga memerlukan data primer dalam bentuk data lapangan untuk menunjang data kepustakaan (data sekunder), sehingga berkarakter penelitian yuridis-empiris (Daud Silalahi, 2001), namun demikian, hasil akhir (out-put) dari penelitian tersebut diformulasikan kembali sebagai suatu penelitian hukum (yuridis).

Penelitian ini menggunakan pendekatan secara yuridis normatif dengan didukung yuridis empiris. Dengan tahapan sebagai berikut :

a. Penelitian Kepustakaan (Library research)

Mengiventarisir data sekunder yaitu data yang didapat dari kepustakaan dengan mengkaji bahan-bahan hukum, baik bahan hukum primer yaitu bahan

Copyright $\odot$ 2015, LITIGASI, p-ISSN: 0853-7100; e-ISSN: 2442-2274 
Available online at: http://ejournal.unpas.ac.id/index.php/litigasi

Litigasi, Vol. 16(1), 2015, 2658-2740

DOI: http://dx.doi.org/10.23969/litigasi.v16i1.51

hukum yang mengikat yaitu peraturan perundang-undangan, bahan hukum sekunder yaitu bahan hukum yang mendukung bahan hukum primer, maupun bahan hukum tersier yang mendukung bahan hukum primer dan bahan hukum sekunder.

b. Penelitian Lapangan (Field research)

Penelitian lapangan dilakukan untuk mendapatkan data primer, dan data tersebut akan dipakai untuk mendukung analisis hasil penelitian kepustakaan. yaitu suatu penelitian terhadap data primer yang berfungsi sebagai data tambahan / data pendukung bagi penelitian kepustakaan sebagai data utama. Penelitian yang dilakukan adalah penelitian terhadap proses advokasi yang selama ini dilakukan terhadap perempuan pelaku tindak pidana kekerasan dalam rumah tangga.

Berdasarkan tahap penelitian yang dilakukan, maka penelitian ini juga diikuti dengan teknik pengumpulan data dengan 2 (dua) cara, yaitu :

a. Studi Kepustakaan/studi literatur ;

Pengumpulan data sekunder menggunakan teknik penelaahan terhadap bahan hukum primer, yaitu bahan hukum yang mengikat seperti peraturan perundang-undangan yang terkait dengan penelitian yang dilakukan; bahan hukum sekunder yang memberikan penjelasan terhadap bahan hukum primer yang peneliti ambil dari doktrin, hasil penelitian lain yang relevan dengan penelitian yang dilakukan, dan bahan hukum tersier yang memberi penjelasan

Copyright @ $\odot$ 2015, LITIGASI, p-ISSN: 0853-7100; e-ISSN: 2442-2274 
Available online at: http://ejournal.unpas.ac.id/index.php/litigasi

Litigasi, Vol. 16(1), 2015, 2658-2740

DOI: http://dx.doi.org/10.23969/litigasi.v16i1.51

terhadap bahan hukum primer maupun bahan hukum sekunder dalam bentuk bibliografi, kamus hukum, jurnal nasional maupun jurnal internasional yang terkait dengan materi yang diteliti dan sebagainya.

b. Studi Lapangan;

Penelitian lapangan dilakukan dengan menggunakan teknik wawancara yang terstruktur terhadap sampel terpilih (purposive sampling), yaitu warga binaan pemasyarakatan dan pihak Lapas (Petugas Lapas). Dalam

praktiknya sampel tersebut dipilih oleh pihak Lapas dengan karakteristik pelaku yang terkait dengan tindak pidana kekerasan dalam rumah (jenis tindak pidana KDRT). Selain wawancara, maka peneliti juga melakukan observasi terhadap proses hukum acara yang berlaku dan pengumpulan data dari lembaga yang terkait.

Guna memberikan kelancaran pada penelitian ini dan untuk mempermudah peneliti memperoleh data primer maupun data sekunder, maka lokasi penelitian yang akan kami gunakan adalah :

a. Penelitian kepustakaan : Perpustakaan BPHN, Perpustakaan UI, Perpustakaan UNPAD, Perpustakaan UNPAS.

b. Penelitian lapangan : Lembaga Pemasyarakatan Wanita KIs IIA Sukamiskin Bandung, Lembaga pemasyarakatan Wanita Dan Anak Kls IIB Tangerang.

Setelah seluruh data yang diperlukan terkumpul, maka data tersebut dianalisis dengan menggunakan analisis secara yuridis kualitatif, analisis yuridis

Copyright @ 9 2015, LITIGASI, p-ISSN: 0853-7100; e-ISSN: 2442-2274 
Available online at: http://ejournal.unpas.ac.id/index.php/litigasi

Litigasi, Vol. 16(1), 2015, 2658-2740

DOI: http://dx.doi.org/10.23969/litigasi.v16i1.51

kualitatif dimaksud adalah suatu bentuk analisis dalam hal data sekunder dan data primer yang telah terkumpul, akan disajikan secara deskriptif untuk dianalisis dan dijelaskan dengan menggunakan metode yuridis-kualitatif. Materi perundangundangan yang terkait dengan kekerasan rumah tangga, kedudukan hukum perempuan baik menurut hukum perdata, hukum perkawinan dan hukum Islam, termasuk juga hukum acara untuk menyelesaikan proses pidana yang dihadapi yang khusus berkaitan dengan proses pendampingan yang berlaku di dalam hukum acara, disistematisir yang kemudian dikaji untuk diketahui korelasi, interdependensi, kontradiktif ketentuan yang berkaitan dengan persoalan kekerasan di dalam rumah tangga yang dilakukan oleh perempuan dan diharapkan peneliti dapat menyajikan konsep pemikiran yang merupakan gagasan tentang pola pendampingan yang tepat untuk mencapai tujuan hukum (keadilan) bagi pelaku tindak pidana kekerasan dalam rumah tangga yang dilakukan oleh perempuan, yang akhirnya menghasilkan output pola pendampingan advokasi mandiri bagi perempuan pelaku tindak pidana di dalam proses peradilan yang menjadi alternatif di dalam litigasi, sehingga outcome yang ingin dicapai adalah adanya pembaharuan hukum dalam proses peradilan di Indonesia.

Copyright @ 9 2015, LITIGASI, p-ISSN: 0853-7100; e-ISSN: 2442-2274 
Available online at: http://ejournal.unpas.ac.id/index.php/litigasi

Litigasi, Vol. 16(1), 2015, 2658-2740

DOI: http://dx.doi.org/10.23969/litigasi.v16i1.51

\section{Desain Analisis I}
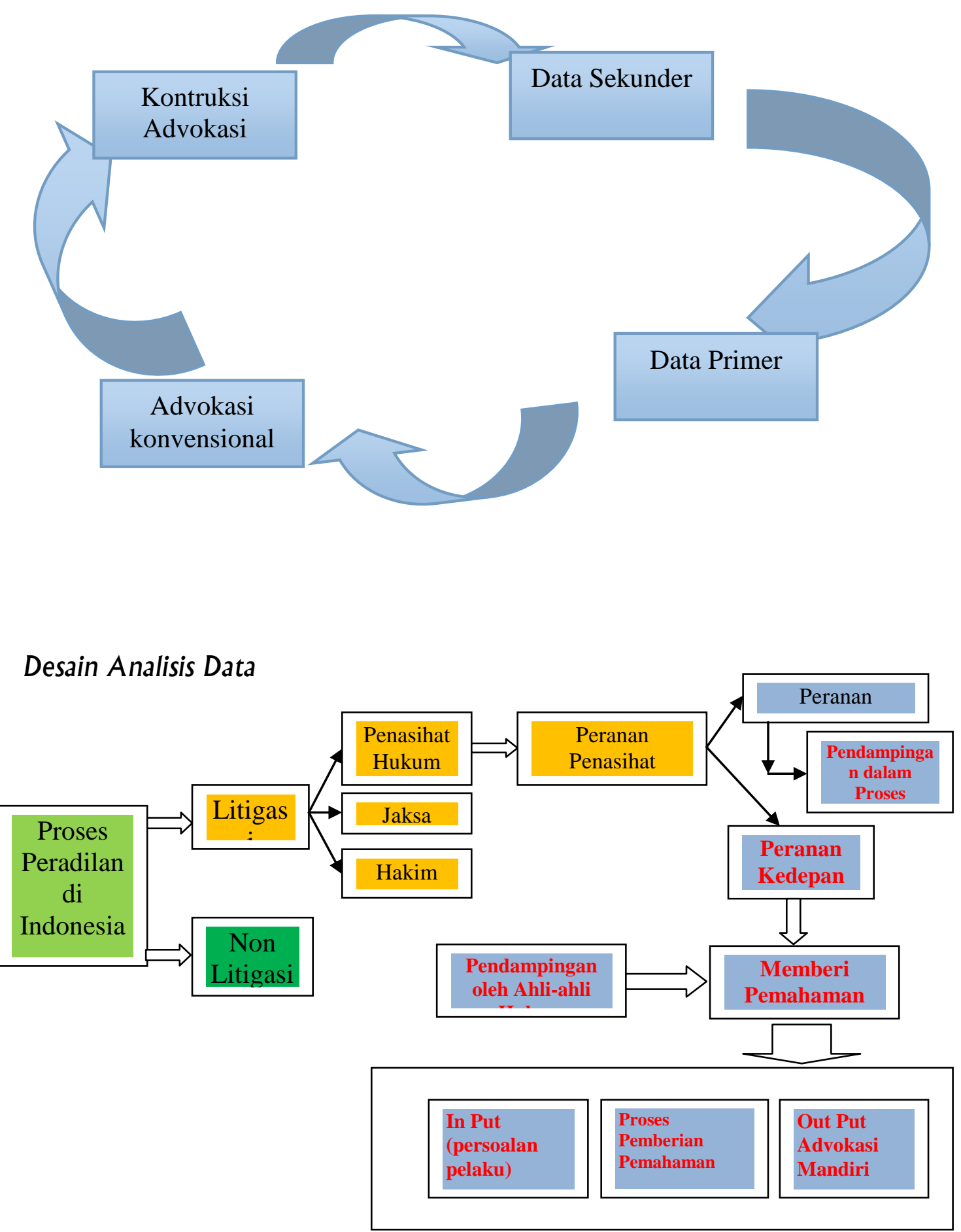

Copyright @ C 2015, LITIGASI, p-ISSN: 0853-7100; e-ISSN: 2442-2274 
Available online at: http://ejournal.unpas.ac.id/index.php/litigasi

Litigasi, Vol. 16(1), 2015, 2658-2740

DOI: http://dx.doi.org/10.23969/litigasi.v16i1.51

\section{HASIL PENELITIAN DAN ANALISIS.}

A. Kajian Terhadap Kekerasan Dalam Rumah Tangga Dan Pelaksanaan Proses Pendampingan Bagi Perempuan Pelaku Tindak Pidana Kasus Kekerasan Dalam Rumah Tangga Yang Berlaku Dalam Praktik

Kekerasan dalam rumah tangga cikal bakal kasusnya muncul dari keluarga, sedangkan komunitas keluarga timbul awalnya dari sebuah perkawinan. Sebuah perkawinan yang ideal merupakan dambaan setiap orang, baik itu laki-laki maupun perempuan. Tidak ada satupun manusia yang menginginkan adanya perpecahan di dalam perkawinan, konflik yang muncul di dalam setiap perkawinan selalu diusahakan mendapatkan jalan keluar yang terbaik bagi perkawinan, tetapi pada kenyataannya banyak kasus yang terjadi di dalam perkawinan menimbulkan konflik yang menghasilkan kekerasan, baik kekerasan terhadap istri ataupun kekerasan terhadap suami termasuk anak-anak, atau anggota keluarga lainnya, baik kekerasan fisik, kekerasan psikhis, kekerasan seksual maupun penelantaran rumah tangga, sehingga tidak jarang menghasilkan konflik yang akhirnya masuk pada ranah hukum pidana.

Berkembangnya persoalan hukum yang mengarah pada kekerasan di dalam rumah tangga banyak diakibatkan oleh berbagai persoalan, baik persoalan yang muncul dari dalam diri sendiri maupun persoalan yang muncul dari luar, salah satu yang sering munculnya persoalan dari luar menurut Lunden (Marlina, 2009) adalah:

Copyright @ 9 2015, LITIGASI, p-ISSN: 0853-7100; e-ISSN: 2442-2274 
Available online at: http://ejournal.unpas.ac.id/index.php/litigasi

Litigasi, Vol. 16(1), 2015, 2658-2740

DOI: http://dx.doi.org/10.23969/litigasi.v16i1.51

1. Besarnya jumlah dan sukarnya melakukan pencegahan terhadap gelombang urbanisasi remaja dari desa ke kota;

2. Terjadinya konflik antar norma adat pedesaan (tradisional) dengan norma baru yang tumbuh dalam proses dan perkembangan kehidupan sosial yang cepat di kota besar;

3. Memudarnya pola-pola kepribadian individu yang terkait kuat pada pola kontrol sosial tradisionalnya, sehingga anggota masyarakat terutama remajanya mulai kehilangan pola kepribadian atau "samar pola" menentukan perilakunya.

Persoalan yang muncul dari dalam diri, dapat diakibatkan karena persoalan yang datang dari diri sendiri maupun datang dari persoalan hubungan rumah tangga, sehingga dari persoalan di atas sering menimbulkan kekerasan di dalam rumah tangga.

Saat ini banyak kekerasan yang dilakukan di dalam rumah tangga melampaui batas kewajaran. Hal ini dapat dilihat di dalam beberapa kasus yang ternyata menimbulkan hilangnya nyawa atau hilangnya kemerdekaan seseorang, sehingga banyak yang berpendapat, bahwa kekerasan dalam rumah tangga yang terjadi di Indonesia harus dikategorikan sebagai kejahatan. Dimasukannya perbuatan kekerasan dalam rumah tangga sebagai suatu kejahatan memiliki alasan mendasar (Rita Serena Kolibonso, 2002) yaitu:

1. Alasan berdasarkan fakta;

KDRT sejauh ini tidak dikenal sebagai kejahatan dalam masyarakat meskipun terjadi di banyak tempat dalam bentuk seperti perkosaan, penyiksaan

Copyright @ 9 2015, LITIGASI, p-ISSN: 0853-7100; e-ISSN: 2442-2274 
Available online at: http://ejournal.unpas.ac.id/index.php/litigasi

Litigasi, Vol. 16(1), 2015, 2658-2740

DOI: http://dx.doi.org/10.23969/litigasi.v16i1.51

terhadap istri, penyiksaan terhadap anak, incest, pemasungan, pembunuhan, dan bentuk kekerasan lannya. Dalam kasus-kasus tertentu, korban yang berupaya melindungi diri dan membalas perlakuan pelaku dengan mencederainya, akhirnya malah dituntut dan dianggap melakukan kejahatan lainnya, seperti pembunuhan. Sejumlah informasi dan studi yang tersedia sudah cukup untuk menunjukan fakta bahwa, perempuan menjadi korban kekerasan karena adanya ketidakseimbangan relasi antara laki-laki dan perempuan, ini terjadi dalam relasi pasangan perkawinan, keluarga dan pasangan intim.

2. Alasan berdasarkan komitmen negara;

Konferensi Dunia tentang Perempuan ke-IV di Beijing (1995), telah melahirkan Deklarasi dan Landasan Aksi. Kekerasan terhadap perempuan termasuk salah satu dari 12 bidang kritis yang dicantumkan dalam landasan aksi tersebut. Pada Sidang Khusus PBB Tentang Perempuan di New York (2000), masalah kekerasan terhadap perempuan tetap menjadi bagian dari sejumlah masalah kritis yang dipantau dan diprihatinkan.

Indonesia sebagai salah satu negara anggota $P B B$ dan negara peserta ratifikasi Konvensi $P B B$, telah meratifikasi Convention on The Elimination of All Forms of Discrimination Against Women (CEDAW) dengan dikeluarkannya Undang-Undang No. 7 Tahun 1984 Tentang Pengesahan Konvensi Penghapusan Segala Bentuk Diskriminasi terhadap Perempuan. Oleh karena itu, sudah seharusnya Indonesia dapat menyelesaikan dan mencegah

Copyright @ C 2015, LITIGASI, p-ISSN: 0853-7100; e-ISSN: 2442-2274 
Available online at: http://ejournal.unpas.ac.id/index.php/litigasi

Litigasi, Vol. 16(1), 2015, 2658-2740

DOI: http://dx.doi.org/10.23969/litigasi.v16i1.51

terjadinya kekerasan terhadap perempuan, walaupun kenyataannya masih banyak terjadi di dalam lingkup keluarga, masyarakat dan negara.

Persoalan-persoalan yang muncul di lapangan pada kekerasan dalam rumah tangga bukan hanya muncul begitu saja, sering terjadi karena dilatarbelakangi oleh perbuatan-perbuatan dari situasi atau kondisi dan peranan dari korban (anggota keluarga), sehingga perbuatan yang dilakukan tidak murni berdiri sendiri, tetapi selalu terdapat hubungan sebab akibat (kausalitas) untuk terjadinya kekerasan dalam rumah tangga. Pada saat sekarang, kekerasan rumah tangga banyak dilakukan oleh perempuan sebagai istri atau sebagai ibu. Hal ini harus dipandang secara komprehensif. Artinya, bahwa perbuatan yang dilakukan banyak dilatarbelakangi oleh perbuatan kekerasan oleh anggota keluarga lainnya di dalam rumah tangga. Kekerasan yang dilakukan umumnya sebagai anti klimak dari perbuatan lain yang diterima, sehingga sering muncul yang seharusnya istri menjadi korban perbuatan berubah menjadi pelaku.

Hukum pidana khususnya KUHP, tidak mengatur secara spesifik tentang perbuatan kekerasan yang dilakukan oleh perempuan. KUHP hanya mengatur perbuatan kekerasan bagi setiap orang (baik laki-laki, perempuan, anak atau dewasa) dan hanya terbatas pada perbuatan fisik saja, tetapi hanya ada satu pasal saja yang tertuju pada perempuan, yaitu Pasal 356 Ayat (1) KUHP, sedangkan undang-undang lain yang mengatur tentang kekerasan di dalam rumah tangga adalah Undang-Undang No. 23 Tahun 2004 Tentang PKDRT. Undang-Undang tersebut mengatur secara spesifik kekerasan yang dilakukan

Copyright @ 9 2015, LITIGASI, p-ISSN: 0853-7100; e-ISSN: 2442-2274 
Available online at: http://ejournal.unpas.ac.id/index.php/litigasi

Litigasi, Vol. 16(1), 2015, 2658-2740

DOI: http://dx.doi.org/10.23969/litigasi.v16i1.51

oleh anggota keluarga terhadap anggota keluarga lainnya. Undang-Undang tersebut memiliki karakteristik yang dikhususkan bagi perempuan, hanya saja tidak ada pasal pun yang mengatur secara khusus apabila perempuan yang menjadi pelaku karena alasan di atas. Padahal, alasan seorang perempuan menjadi pelaku kekerasan karena anti klimaks dari perbuatan korban.

Di dalam Undang-Undang No. 23 Tahun 2004 terdapat pasal yang mengatur tentang bentuk pendampingan atau perlindungan yang harus dilakukan terhadap korban, dari mulai Pasal 16 sampai dengan Pasal 38, termasuk pasal yang mengatur pemulihan bagi korban, yaitu dari mulai Pasal 39 sampai dengan Pasal 43. Undang-Undang No. 23 Tahun 2004 tersebut tidak mengatur bentuk perlindungan dan pemulihan apabila perempuan sebagi istri yang menjadi pelaku. Padahal menurut peneliti ini sangat penting untuk dilakukan mengingat perbuatan yang dilakukan memiliki latar belakang sebagai korban, sehingga sering sekali di dalam praktik/proses peradilan motif dan latar belakang pelaku melakukan tindakan kekerasan tidak muncul/mencuat ke permukaan. Seharusnya latar belakang tersebut menjadi sangat penting untuk diungkapkan di dalam proses pemeriksaan guna putusan hakim yang benar dan adil.

Bentuk pendampingan yang dapat diberikan kepada pelaku tetap mengacu kepada Undang-Undang No. 8 Tahun 1981 Tentang Kitab UndangUndang Hukum Acara Pidana, sebagaimana diamanatkan oleh UndangUndang No. 23 Tahun 2004 yang dituangkan dalam Pasal 54 yang berisi

Copyright @ C 2015, LITIGASI, p-ISSN: 0853-7100; e-ISSN: 2442-2274 
Available online at: http://ejournal.unpas.ac.id/index.php/litigasi

Litigasi, Vol. 16(1), 2015, 2658-2740

DOI: http://dx.doi.org/10.23969/litigasi.v16i1.51

penyidikan, penuntutan, dan pemeriksaan di sidang pengadilan dilaksanakan menurut ketentuan hukum acara pidana yang berlaku, kecuali ditentukan lain dalam undang-undang ini.

Ketentuan lain yang terdapat di dalam undang-undang tersebut hanya untuk pengaturan alat bukti yang menyimpang dari ketentuan yang terdapat di dalam KUHAP. Mendasarkan kepada Undang-Undang PKDRT di atas, maka pendampingan yang dilakukan mengacu kepada Pasal 69 sampai dengan Pasal 74 KUHAP.

Berdasarkan amanat dari pasal di atas, maka bentuk pendampingan yang dilakukan dapat dimulai pada saat pelaku ditangkap atau ditahan pada semua tingkat pemeriksaan, dan tata cara pendampingan tetap mengacu kepada undang-undang ini. Peran pendamping penasihat hukum sangat besar artinya bagi penyelesaian tindak pidana tersebut. Sebab, pendamping penasihat hukum menurut Pasal 70 ayat (1) KUHAP dapat menghubungi, berbicara dengan tersangka pada setiap tingkat pemeriksaan dan setiap waktu untuk kepentingan pembelaan perkaranya, disamping juga bahwa pendamping berhak mengirim dan menerima surat dari tersangka setiap kali dikehendaki olehnya.

Kenyataannya tugas pendampingan yang dilakukan oleh penasihat hukum tidak memberikan pemahaman atau menumbuhkan pemahaman hukum bagi pelaku perempuan. Pada praktiknya, ternyata pendampingan hanya dilakukan pada saat pelaku berada di dalam proses peradilan saja, dan bertemu dengan pelaku juga pada saat proses pemeriksaan akan dilakukan.

Copyright @ C 2015, LITIGASI, p-ISSN: 0853-7100; e-ISSN: 2442-2274 
Available online at: http://ejournal.unpas.ac.id/index.php/litigasi

Litigasi, Vol. 16(1), 2015, 2658-2740

DOI: http://dx.doi.org/10.23969/litigasi.v16i1.51

Pendampingan tidak pernah dilakukan sebelum proses pemeriksaan akan dilakukan, padahal seharusnya pendampingan dilakukan baik pada saat di dalam proses hukum acara maupun diluar proses hukum acara. Sebaiknya justru pendampingan berfungsi sebagai upaya untuk memberikan pemahaman hukum bagi pelaku sehingga mereka dapat memahami posisi atau kedudukan hukum, terutama pada saat akan dilakukan pembelaan. Hal ini penting dilakukan karena perbuatan yang dilakukan tersebut memiliki latar belakang perbuatan lain yang mengandung kekerasan. Seperti hasil wawancara peneliti dengan para tahanan di Lapas wanita KIs IIA Bandung dan Lapas wanita dan anak Kls IIB Tangerang. Dari keterangan yang disampaikan oleh para tahanan wanita, maka umumnya proses pendampingan yang dilakukan hanya terbatas pada proses pendampingan di dalam pengadilan saja. Proses pendampingan yang dilakukan tidak dimulai semenjak mereka ditahan dan tidak dilakukan semenjak mereka akan menjalankan proses hukum acara, sehingga pembelaan yang diharapkan dapat dilakukan oleh penasihat hukum sebagai tugas dari lembaga bantuan hukum dapat dilaksanakan secara maksimal tidak tercapai.

Berikut ini adalah hasil wawancara yang dilakukan peneliti baik kepada wanita pelaku kekerasan dalam rumah tangga, maupun kepada petugas Lapas yang berfungsi sebagai pengawas penitipan tahanan wanita. Adapun hasil wawancara yang kami lakukan dengan tahanan wanita (sedang dalam proses hukum), dapat diambil suatu kesimpulan, sebagai berikut:

Copyright @ C 2015, LITIGASI, p-ISSN: 0853-7100; e-ISSN: 2442-2274 
Available online at: http://ejournal.unpas.ac.id/index.php/litigasi

Litigasi, Vol. 16(1), 2015, 2658-2740

DOI: http://dx.doi.org/10.23969/litigasi.v16i1.51

1. Jenis perbuatan yang dilakukan ;

Umumnya perbuatan yang dilakukan oleh pelaku wanita adalah kejahatan terhadap nyawa, kejahatan terhadap tubuh, maupun kejahatan harta kekayaan, sedangkan perbuatan yang banyak dilakukan oleh anak adalah narkotika. Kekerasan atau perbuatan lainnya sering dilakukan terhadap anggota keluarga sendiri maupun terhadap orang lain (pihak ke-3) yang ada hubungannya dengan kekerasan rumah tangga. Baik perbuatan itu dilakukan terhadap suami, terhadap anak kandung, anak tiri, terhadap orang tua (mertua), maupun terhadap orang lain, sehingga mereka dijerat oleh pasal-pasal yang terdapat di dalam KUHP maupun pasal-pasal yang ada di Iuar KUHP.

2. Latar belakang dilakukannya perbuatan;

Kekerasan/perbuatan yang dilakukan oleh pelaku wanita tersebut umumnya berlatar belakang kekerasan rumah tangga yang dialami selama bertahuntahun. Perbuatan yang dilakukan merupakan suatu hasil dari proses akibat yang sangat panjang, sehingga perbuatan yang dilakukan merupakan perbuatan klimaks yang tidak dapat dicegah. Hal ini sesuai dengan kondisi perempuan di dalam masyarakat yang masih dianggap sebagai sub-ordinat dari peran suami sebagai kepala rumah tangga, selain pemahaman kedudukan istri menurut hukum Islam yang penerapannya salah, yaitu bahwa pendidikan yang diterapkan oleh suami terhadap istri adalah pendidikan yang tidak boleh dibantah, karena apabila dibantah suami memiliki pembenaran untuk

Copyright $\odot$ 2015, LITIGASI, p-ISSN: 0853-7100; e-ISSN: 2442-2274 
Available online at: http://ejournal.unpas.ac.id/index.php/litigasi

Litigasi, Vol. 16(1), 2015, 2658-2740

DOI: http://dx.doi.org/10.23969/litigasi.v16i1.51

memperlakukan istri secara sewenang-wenang. Selain itu, selama ini persepsi yang selama ini berlaku di masyarakat bahwa kekerasan di dalam rumah tangga masih dianggap bukan sebagai kejahatan meskipun perbuatan yang dilakukan masuk ke dalam kategori kejahatan, yaitu kekerasan fisik, kekerasan seksual (paksaan untuk melakukan persetubuhan), penyiksaan terhadap anak, pemasungan dan lain sebagainya. Masyarakat masih beranggapan apabila perbuatan tersebut dilakukan oleh suami maka posisi kesalahan selalu berada di pihak istri, apalagi apabila istri melakukan perlawanan terhadap suami dengan mencederainya, justru akhirnya malah istri yang dituntut dan dianggap sebagai pelaku kekerasan dalam rumah tangga. Para keluarga korban ataupun pelaku, juga tetangga yang menyaksikan perbuatan pelaku sering menganggap bahwa itu bukan menjadi urusan umum, tetapi itu adalah urusan pribadi dari rumah tangga pelaku dan korban, sehingga kepekaan masyarakat terhadap perbuatan kekerasan sangat minim. Selanjutnya yang melatarbelakangi perbuatan kekerasan yang dilakukan perempuan adalah karena penelantaran yang dilakukan oleh suami terhadap keluarga, sehingga menimbulkan tekanan ekonomi dan tekanan psikologi yang berkepanjangan sehingga menghasilkan ketidak seimbangan emosional, selain itu juga yang banyak dialami oleh pelaku adalah kombinasi ketiga kekerasan di atas.

Copyright @ $\odot$ 2015, LITIGASI, p-ISSN: 0853-7100; e-ISSN: 2442-2274 
Available online at: http://ejournal.unpas.ac.id/index.php/litigasi

Litigasi, Vol. 16(1), 2015, 2658-2740

DOI: http://dx.doi.org/10.23969/litigasi.v16i1.51

3. Proses pendampingan yang dilakukan oleh penasihat hukum selama proses hukum acara berlangsung;

Apabila melihat profesi advokat sebagai lembaga yang berfungsi memberikan bantuan hukum, maka profesi tersebut memiliki peranan yang sangat strategis dan mulia untuk membantu dan menegakan hukum dengan benar. Sebab, moralitas profesi advokat sebagai penasihat hukum merupakan sesuatu yang mutlak diperlukan dan harus dilaksanakan dalam kehidupan kerjanya. Menurut Sidharta (Sidharta, 2006) bahwa moralitas seorang advokat dapat dinilai dengan penilaian umum, yakni standar normatif evaluasi (normative standards of evaluation) dan aturan normatif perilaku (normative rules of conduct).

Sebagai aktualisasi moralitas yang harus dimiliki oleh seorang advokat adalah pada saat adanya hubungan antara advokat dengan klien-nya, maka advokat memiliki kewajiban untuk memberikan perlindungan dan pembelaan atas perkara yang dihadapinya, sehingga karena hubungan tersebut dengan moralitas seorang advokat, maka kewajiban tersebut dituangkan dan diikat dalam kode etik profesi advokat.

Apabila melihat dari isi Pasal 4 Kode Etik Profesi Advokat Indonesia tertanggal 23 Mei 2002, maka advokat memiliki kewajiban sebagai berikut:

a. Advokat dalam perkara-perkara perdata harus mengutamakan penyelesaian dengan jalan damai;

Copyright $\odot$ 2015, LITIGASI, p-ISSN: 0853-7100; e-ISSN: 2442-2274 
Available online at: http://ejournal.unpas.ac.id/index.php/litigasi

Litigasi, Vol. 16(1), 2015, 2658-2740

DOI: http://dx.doi.org/10.23969/litigasi.v16i1.51

b. Advokat tidak dibenarkan memberikan keterangan yang dapat menyesatkan klien mengenai perkara yang sedang diurusnya;

c. Advokat tidak dibenarkan menjamin kepada kliennya bahwa perkara yang ditanganinya akan menang;

d. Dalam menentukan besarnya honorarium advokat wajib mempertimbangkan kemampuan klien;

e. Advokat tidak dibenarkan membebani klien dengan biaya-biaya yang tidak perlu;

f. Advokat dalam mengurus perkara cuma-cuma harus memberikan perhatian yang sama seperti terhadap perkara untuk mana ia menerima uang jasa;

g. Advokat harus menolak mengurus perkara yang menurut keyakinannya tidak ada dasar hukumnya;

h. Advokat wajib memegang rahasia jabatan tentang hal-hal diberitahukan oleh klien secara kepercayaan dan wajib tetap menjaga rahasia itu setelah berakhirnya hubungan antara advokat dan klien itu;

i. Advokat tidak dibenarkan melepaskan tugas yang dibebankan kepadanya pada saat yang tidak menguntungkan posisi klien atau pada saat tugas itu akan dapat menimbulkan kerugian yang tidak dapat diperbaiki lagi bagi klien yang bersangkutan, dengan tidak mengurangi ketentuan sebagaimana dimaksud dalam Pasal 3 huruf (a);

Copyright (C) 2015, LITIGASI, p-ISSN: 0853-7100; e-ISSN: 2442-2274 
Available online at: http://ejournal.unpas.ac.id/index.php/litigasi

Litigasi, Vol. 16(1), 2015, 2658-2740

DOI: http://dx.doi.org/10.23969/litigasi.v16i1.51

1) Advokat yang mengurus kepentingan bersama dari dua pihak atau lebih harus mengundurkan diri sepenuhnya dari pengurusan kepentingankepentingan tersebut, apabila dikemudian hari timbul pertentangan kepentingan antara pihak-pihak yang bersangkutan;

2) Hak retensi advokat terhadap klien diakui sepanjang tidak akan menimbulkan kerugian kepentingan klien.

Apabila memperhatikan Pasal 4 kode etik profesi advokat di atas, maka tidak diatur secara jelas kewajiban advokat untuk menjelaskan dan memberikan pemahaman hukum kepada klien tentang persoalan hukum/perkara yang sedang dihadapi, tugas pembelaan diserahkan kepada advokat/penasihat hukum, sehingga pembelaan sepenuhnya diserahkan kepada penasihat hukum, sehingga seorang pelaku punya kewajiban untuk menyerahkan persoalan hukumnya kepada penasihat hukum tanpa diberikan pemahaman hukumnya.

Kenyataannya di lapangan menunjukkan bahwa, penasihat hukum hanya mendampingi pelaku pada saat di dalam pengadilan saja, sedangkan di luar pengadilan penasihat hukum tidak merasa memiliki kewajiban untuk mendampingi atau membela pelaku. Berdasarkan hasil penelitian, secara umum pelaku tindak pidana menjelaskan sebagai berikut :

a. Tersangka ditawari pendamping akan tetapi tersangka tidak mengerti dan tidak tahu apa yang dimaksud pendampingan dalam pemeriksaan dan penyidikan atas kasusnya.

Copyright @ 9 2015, LITIGASI, p-ISSN: 0853-7100; e-ISSN: 2442-2274 
Available online at: http://ejournal.unpas.ac.id/index.php/litigasi

Litigasi, Vol. 16(1), 2015, 2658-2740

DOI: http://dx.doi.org/10.23969/litigasi.v16i1.51

b. Tersangka tidak mau diberikan pendamping dengan beberapa alasan, yaitu kekhawatiran harus membayar mahal, pendamping tidak membantu mereka, pendamping tidak peduli terhadap nasib mereka, pendamping tidak lebih hanya menjalankan tugas alakadarnya untuk memenuhi kewajiban formalitas saja, pendamping lebih berorientasi menggampang dan menyelesaikan masalah dengan imbalan uang yang akan diberikan kepada aparat penegak hukum. Sebagian besar warga binaan tidak dapat memenuhi permintaan pendamping karena bagaimana mungkin memperoleh uang pada keadaan mereka berada di $L P$, sedangkan suami mereka pun tidak membantu.

c. Bagi yang mampu ada yang menggunakan penasihat hukum atau pengacara hanya sayangnya ada pengacara yang memanfaatkan situasi tersangka khususnya kasus narkoba dengan meminta imbalan yang berlebihan. Ada pula mereka yang didampingi oleh pendamping yang ditunjuk sendiri atau pihak keluarga, namun dari beberapa pendapat, pendamping itupun lebih berorientasi pada uang. Mereka membutuhkan pendamping yang dapat menjelaskan dan memberikan pemahaman untuk membela hak-hak mereka, sekalipun mereka harus mengungkapkan dan membela diri sendiri di persidangan secara mandiri. Mereka membutuhkan bekal ilmu pengetahuan tentang kasus yang menimpanya, dan pengetahuan untuk membela dan meringankan hukuman, serta pemahaman terhadap akibat hukum yang timbul. 
Available online at: http://ejournal.unpas.ac.id/index.php/litigasi

Litigasi, Vol. 16(1), 2015, 2658-2740

DOI: http://dx.doi.org/10.23969/litigasi.v16i1.51

d. Ada pula pendamping yang diupayakan adanya oleh lembaga gereja. Warga binaan tidak dipungut biaya semua yang menanggung biaya pihak gereja. Hasil wawancara diperoleh data bahwa, bentuk dan proses pendampingan dilakukan secara konvensional. Bentuk pendampingan di LP Wanita Bandung lebih banyak pendampingan pribadi. Sekalipun ada pendampingan yang disediakan oleh negara. Bantuan hukum kepada tersangka dan terdakwa dalam setiap tingkat pemeriksaan proses peradilan pidana adalah advokat. Namun hal tersebut tidak mengikat. Artinya, pendampingan tersebut dapat ada dan tidak ada. Saksi dapat saja didampingi oleh advokat jika diperlukan. Bentuk pendampingan hanya bersifat pasif. Pendamping yang hanya bertemu pada saat persidangan. Beberapa saat sebelum proses persidangan berlangsung, pendamping hanya mengarahkan untuk berbicara jujur. Bahkan ada yang menyatakan untuk mengiyakan pada apa yang didakwakan dalam berita acara meskipun berita.

e. Acaranya tidak sesuai dengan materi perbuatan yang dilakukan. Seringkali tersangka atau terdakwa berada pada tekanan pendamping yang menganjurkan untuk mengiyakan berita acara. Oleh karena itu, menurut mereka kebedaan pendampingan tidak membantu, terutama pendamping yang disediakan oleh negara. Pendamping seolah hanya memenuhi kewajiban formalitas atas tugas yang diembannya. Lebih bersifat kuantitatif dari kualitatif untuk mendampingi pelaku. Proses pendampingan hanya berlangsung sesaat sebelum sidang dimulai. Pendamping tidak sampai pada pemberian pengetahuan dan 
Available online at: http://ejournal.unpas.ac.id/index.php/litigasi

Litigasi, Vol. 16(1), 2015, 2658-2740

DOI: http://dx.doi.org/10.23969/litigasi.v16i1.51

pemahaman pada posisi hukum pelaku tindak pidana. Dengan demikian, para tersangka atau terdakwa lebih dibiarkan pada nalarnya sendiri untuk membela hak-haknya. Menurut warga binaan, tidak ada bekal persiapan sama sekali yang diberikan oleh pendamping ketika akan menghadapi persidangan. Terkecuali untuk pendampingan yang disediakan oleh pribadi, ada efektifitasnya. Namun persoalannya tergantung pada kepedulian keluarga dan finansial yang harus dibayarnya dengan harga mahal, sedang pelaku tidak dapat mencari finansial sehubungan ada di $L P$.

Berbeda dengan proses pendampingan terhadap anak wanita (Lapas anak wanita Klas IIB Tangerang) yang menjadi pelaku tindak pidana, maka berdasarkan hasil penelitian dapat dijelaskan bahwa Balai Pemasyarakatan (BAPAS) yang ditunjuk oleh pemerintah memiliki kewajiban untuk mendampingi anak baik di dalam proses hukum acara maupun di luar proses hukum acara. BAPAS memiliki kewajiban untuk memberikan pelayanan hukum bagi anak, dan proses tersebut telah berjalan sesuai dengan ketentuanya, hanya saja dalam pelaksanaanya masih terkendala yaitu kurangnya pemahaman yang dimiliki/kurangnya sosialisasi fungsi BAPAS terhadap anak, sehingga menimbulkan reaksi penolakan dari anak yang berhadapan dengan hukum, selain itu juga yang masih menjadi kendala di lapangan adalah jumlah personil yang kurang memadai, terutama mengingat jumlah kasus hukum pidana yang dihadapi oleh anak wanita semakin banyak dengan kasus yang semakin beragam.

Copyright $\odot$ 2015, LITIGASI, p-ISSN: 0853-7100; e-ISSN: 2442-2274 
Available online at: http://ejournal.unpas.ac.id/index.php/litigasi

Litigasi, Vol. 16(1), 2015, 2658-2740

DOI: http://dx.doi.org/10.23969/litigasi.v16i1.51

Berdasarkan hasil penelitian lapangan yang kami lakukan, perlu dilakukan upaya untuk membuat suatu alternatif pendampingan yang berkesinambungan diluar dari proses pendampingan yang sudah diatur oleh undang-undang yang justru memiliki peranan sangat besar untuk menimbulkan kesadaran bagi pelaku tentang kedudukan hukumnya, sehingga akan menjadi bahan pembelaan dan pemberdayaan bagi wanita pelaku kekerasan untuk menyelesaikan kasus hukumnya, sehingga marginalisasi perempuan di depan hukum terus diupayakan dihilangkan.

B. Konsep Pola Pendampingan Sebagai Upaya Advokasi Mandiri Yang Ditawarkan Dalam Pembaharuan Proses Peradilan

Pendampingan bagi pelaku tindak pidana memiliki peranan yang sangat besar bagi penegakan hukum. Hal ini dikarenakan proses pendampingan sebagai upaya pembanding bagi aparat-aparat penegak hukum lainnya yang berfungsi sebagai wakil negara dalam mengadili pelaku yang melakukan tindak pidana. Kekhawatiran tindakan-tindakan represif dan penyalahgunaan wewenang yang dilakukan oleh aparat penegak hukum diharapkan akan diminimalisir oleh adanya proses pendampingan.

Berdasarkan kenyataan di lapangan sebagaimana telah diuraikan di atas, dengan pola pendampingan mandiri sebagai konsep baru diharapkan menumbuh kembangkan kesadaran pelaku untuk membela hak-haknya sendiri

Copyright @ $\odot$ 2015, LITIGASI, p-ISSN: 0853-7100; e-ISSN: 2442-2274 
Available online at: http://ejournal.unpas.ac.id/index.php/litigasi

Litigasi, Vol. 16(1), 2015, 2658-2740

DOI: http://dx.doi.org/10.23969/litigasi.v16i1.51

karena mereka memiliki bekal pengetahuan yang cukup tentang kedudukan hukum dan pemahaman hukum terkait kasus yang dihadapinya.

Guna merealisasikan kesadaran hukum pelaku, maka peranan para ahli hukum khususnya dan peranan para ahli ilmu lainnya sangat besar artinya dalam menumbuh kembangkan kesadaran tersebut, sehingga pada saat proses hukum acara berlangsung baik sejak tahap awal sampai pada tahap peradilan, maka pendamping sebaiknya terus melayani atau mendampingi pelaku yang berada di luar sistem hukum acara. Pendampingan dilakukan untuk memberikan materi-materi hukum yang dibutuhkan sampai pelaku dapat membela dirinya sendiri. Materi-materi hukum tersebut dituangkan dalam bentuk model pembelajaran yang akan dijadikan petunjuk (guidance) bagi perempuan pelaku tindak pidana. Dengan demikian, walaupun pendamping adakalanya tidak dapat mendampingi setiap waktu selama proses hukum acara berlangsung, tetapi pelaku dapat mempelajari buku pedoman yang dibuat pendamping yang dapat dijadikan sebagai bahan ajar guna proses pembelaan yang akan dilakukan oleh pelaku.

Bahan ajar berupa modul yang dibuat adalah bahan ajar yang berkaitan dengan penelitian kami, yaitu bahan ajar yang dapat memiliki kontribusi terhadap pelaku dalam memahami kedudukan hukum mereka baik di dalam proses hukum acara maupun kedudukan hukum dari persolan hukum/perkara yang sedang dihadapi. Hal ini mengingat perbuatan kekerasan rumah tangga yang dilakukan perempuan pelaku tindak pidana

Copyright $\odot$ 2015, LITIGASI, p-ISSN: 0853-7100; e-ISSN: 2442-2274 
Available online at: http://ejournal.unpas.ac.id/index.php/litigasi

Litigasi, Vol. 16(1), 2015, 2658-2740

DOI: http://dx.doi.org/10.23969/litigasi.v16i1.51

belum tentu sepenuhnya karena kesalahan pelaku tetapi merupakan reaksi dari perbuatan-perbuatan lain yang dihadapi oleh pelaku, atau dapat diistilahkan bahwa pelaku korban sebenarnya adalah korban. Bahan ajar yang berupa modul ini, diharapkan dapat menjadi pedoman bagi pelaku untuk mengetahui hak dan kewajibannya di lapangan hukum perkawinan, sehingga dia dapat membela dirinya sendiri walaupun tidak didampingi oleh penasihat hukum selama proses hukum acara berlangsung khususnya di depan pengadilan dan diharapkan perlakuan yang adil dapat diterapkan oleh hakim yang menangani perkara kekerasan tersebut, dan diharapkan konsep ini menjadi terobosan di dalam proses peradilan Indonesia.

Materi-materi muatan untuk pendampingan dan advokasi mandiri dituangkan dalam konsep bahan ajar berupa modul, antara lain berisi tentang:

\section{Pemahaman Kekerasan Dalam Rumah Tangga;}

2. Pemahaman Kedudukan hukum anggota keluarga (khususnya istri) di dalam Perkawinan berdasarkan Undang-Undang perkawinan;

3. Pembaharuan proses peradilan.

Adapun pemahaman hukum yang akan dituangkan di dalam buku ajar dalam bentuk modul adalah :

1. Pemahaman Kekerasan Dalam Rumah Tangga;

Kekerasan yang sering terjadi di masyarakat. Pelakunya tidak hanya orang yang tidak dikenal oleh korban, tetapi pada sat sekarang ini kekerasan banyak dilakukan oleh orang-orang yang paling dekat dengan

Copyright $\odot$ 2015, LITIGASI, p-ISSN: 0853-7100; e-ISSN: 2442-2274 
Available online at: http://ejournal.unpas.ac.id/index.php/litigasi

Litigasi, Vol. 16(1), 2015, 2658-2740

DOI: http://dx.doi.org/10.23969/litigasi.v16i1.51

korban. Salah satu kekerasan yang sering muncul terjadi di dalam rumah tangga.

Menurut Undang-Undang No. 23 Tahun 2004 Pasal 1, “Kekerasan rumah tangga dapat diartikan setiap perbuatan terhadap seseorang terutama perempuan, yang berakibat timbulnya kesengsaraan atau penderitaan secara fisik, seksual, psikologis, dan/atau penelantaran rumah tangga termasuk ancaman untuk melakukan perbuatan pemaksaan, atau perampasan kemerdekaan secara melawan hukum dalam lingkup rumah tangga". Kekerasan terhadap perempuan sudah diatur pula dalam Pasal 1 Deklarasi Penghapusan Kekerasan Terhadap Perempuan (Declaration On The Elimination of Violence Against Women) Tahun 1993, menyatakan bahwa:

“Kekerasan terhadap perempuan adalah setiap tindakan berdasarkan jenis kelamin (gender based violence) yang berakibat kesengsaraan atau penderitaan perempuan secara fisik, seksual, atau psikologis, termasuk ancaman tindakan tertentu, pemaksaan atau perampasan kemerdekaan secara sewenang-wenang, baik yang terjadi di depan umum ataupun dalam kehidupan pribadi." (Declaration On The Elimination of Violence Against Women - CEDAW) Tahun 1993 telah diratifikasi oleh Indonesia yang dituangkan dalam Undang-Undang No. 7 Tahun 1984 Tentang Pengesahan Konvensi Mengenai Penghapusan Segala Bentuk Diskriminasi Terhadap Wanita. Selain itu juga diatur di dalam

Copyright $\odot$ 2015, LITIGASI, p-ISSN: 0853-7100; e-ISSN: 2442-2274 
Available online at: http://ejournal.unpas.ac.id/index.php/litigasi

Litigasi, Vol. 16(1), 2015, 2658-2740

DOI: http://dx.doi.org/10.23969/litigasi.v16i1.51

Undang-Undang No. 23 Tahun 2004 Tentang Penghapusan Kekerasan Dalam Rumah Tangga.

Bentuk kekerasan yang diatur oleh Undang-Undang PKDRT tidak jauh berbeda dengan bentuk kekerasan yang diatur di dalam deklarasi di atas, yaitu antara lain :

1. Kekerasan fisik;

2. Kekerasan psikis/psikologi;

3. Kekerasan seksual;

4. Penelantaran rumah tangga.

Perbedaan antara Undang-Undang No. 23 Tahun 2004 dengan Convensi CEDAW bahwa pada deklarasi mencantukan satu jenis kekerasan lain, yaitu perampasan kemerdekaan secara sewenang-wenang adalah semua perbuatan yang menyebabkan terisolirnya seseorang dari lingkungan sosialnya (penjelasan: diantaranya larangan keluar rumah, larangan komunikasi dengan orang lain) (Komariah Emong Sapardjaja, 2010).

Penghapusan Kekerasan dalam Rumah Tangga adalah jaminan yang diberikan oleh negara untuk mencegah terjadinya kekerasan dalam rumah tangga, menindak pelaku dalam rumah tangga, dan melindungi korban kekerasan dalam rumah tangga. Kekerasan di dalam rumah tangga tidak hanya dapat dilakukan oleh laki-laki saja, tetapi juga oleh siapapun yang ada di dalam lingkup keluarga atau rumah tangga, begitupun yang dapat

Copyright @ 2015 , LITIGASI, p-ISSN: 0853-7100; e-ISSN: 2442-2274 
Available online at: http://ejournal.unpas.ac.id/index.php/litigasi

Litigasi, Vol. 16(1), 2015, 2658-2740

DOI: http://dx.doi.org/10.23969/litigasi.v16i1.51

menjadi korban dari kekerasan, tidak hanya perempuan, tetapi juga bisa siapa saja, sehingga di dalam undang-undang tersebut diatur pula siapa saja yang dapat menjadi korban, yaitu :

Pasal 2 Lingkup rumah tangga dalam undang-undang ini meliputi:

1. Suami, isteri, dan anak;

2. Orang-orang yang mempunyai hubungan keluarga dengan orang sebagaimana dimaksud pada huruf a karena hubungan darah, perkawinan, persusuan, pengasuhan, dan perwalian, yang menetap dalam rumah tangga; dan/atau

3. Orang yang bekerja membantu rumah tangga dan menetap dalam rumah tangga tersebut.

Saat terjadi kekerasan terhadap salah satu anggota keluarga, maka upaya penyelesaian kekerasan tersebut harus dilakukan dengan mendasarkan kepada Pasal 3, yaitu harus dilandaskan pada :

Penghapusan kekerasan dalam rumah tangga dilaksanakan berdasarkan asas:

1. Penghormatan hak asasi;

2. Keadilan dan kesetaraan gender;

3. Nondiskriminasi; dan

4. Perlindungan korban.

Copyright @ $\odot$ 2015, LITIGASI, p-ISSN: 0853-7100; e-ISSN: 2442-2274 
Available online at: http://ejournal.unpas.ac.id/index.php/litigasi

Litigasi, Vol. 16(1), 2015, 2658-2740

DOI: http://dx.doi.org/10.23969/litigasi.v16i1.51

Jenis kekerasan yang dilakukan oleh anggota keluarga banyak yang dilakukan tidak harus selalu dalam bentuk kekerasan fisik, tetapi juga perbuatan-perbuatan lain yang juga dapat menyebabkan sakitnya atau dapat menghilangkan kemampuan seseorang untuk berkembang, sehingga di dalam undang-undang tersebut diatur suatu perbuatan yang lebih luas dibandingkan dengan perbuatan kekerasan yang ada di dalam KUHP. Hukum pidana mengatur jenis perbuatan tersebut tidak hanya memperhatikan kepada kepentingan masyarakat, tetapi yang lebih penting adalah memperhatikan kepentingan hukum individu, sehingga dari semua jenis perbuatan di atas, diatur dalam bentuk delik aduan, hal ini dimaksudkan dalam rangka untuk melindungi korban kepentingan hukumnya diserahkan pada individu si korban, negara tidak akan turut campur atau menyelesaikan persoalan tersebut selama si korban tidak mengadukan persoalan tersebut kepada negara, dan itu yang menjadi ciri dari domestic violence.

Di dalam undang-undang diatur suatu bentuk perlindungan hukum bagi korban yang mengalami kekerasan, hanya saja bentuk perlindungan tersebut tidak diberikan kepada pelaku kekerasan, walaupun apabila melihat dari beberapa kasus yang terjadi dilapangan, terutama yang dilakukan oleh perempuan, kekerasan yang dilakukan sering dilatarbelakangi oleh perbuatan lain yang mengancannya, baik yang dilakukan oleh suami atau oleh anggota keluarga lainnya.

Copyright $@$ 2015, LITIGASI, p-ISSN: 0853-7100; e-ISSN: 2442-2274 
Available online at: http://ejournal.unpas.ac.id/index.php/litigasi

Litigasi, Vol. 16(1), 2015, 2658-2740

DOI: http://dx.doi.org/10.23969/litigasi.v16i1.51

Adapun bentuk perlindungan yang diberikan oleh undang-undang kepada korban telah diatur dalam Pasal 10. Korban berhak mendapatkan:

1. Perlindungan dari pihak keluarga, kepolisian, kejaksaan, pengadilan, advokat, lembaga sosial, atau pihak lainnya baik sementara maupun berdasarkan penetapan perintah perlindungan dari pengadilan;

2. Pelayanan kesehatan sesuai dengan kebutuhan medis;

3. Penanganan secara khusus berkaitan dengan kerahasiaan korban;

4. Pendampingan oleh pekerja sosial dan bantuan hukum pada setiap tingkat proses pemeriksaan sesuai dengan ketentuan peraturan perundang-undangan; dan

5. Pelayanan bimbingan rohani.

Materi buku ajar yang dimuat dalam modul tersebut dibahas pula tentang kedudukan hukum anggota keluarga menurut Undang-Undang perkawinan. Selain itu dibahas pula polemik pernikahan dan perlindungan hukum terhadap perempuan. Polemik pernikahan ini kiranya perlu dibahas mengingat, berkecenderungan menjadi sumber kekerasan dalam rumah tangga, dan membawa korban bagi anggota keluarga. Pelaku kasus KDRT harus memahami akibat hukum dari pernikahan yang bertendensi menimbulkan KDRT.

Copyright @ C 2015, LITIGASI, p-ISSN: 0853-7100; e-ISSN: 2442-2274 
Available online at: http://ejournal.unpas.ac.id/index.php/litigasi

Litigasi, Vol. 16(1), 2015, 2658-2740

DOI: http://dx.doi.org/10.23969/litigasi.v16i1.51

2. Pemahaman Kedudukan Hukum Anggota Keluarga (Istri) di dalam Perkawinan Berdasarkan Undang-Undang;

a. Perempuan Dan Hukum Keluarga

Kerangka hukum yang responsif, desakan untuk perubahan hukum merupakan hal yang wajar. Sebab, hukum seharusnya dilihat sebagai sebuah aturan yang lekat dengan realitas sosial. Adanya realitas sosial yang berubah, biasanya diikuti dengan rasa keadilan masyarakat yang berubah, dan semestinya hukum pun mengalami perubahan (Soerjono Soekanto, 1990). Realitas kehidupan masyarakat, khususnya relasi laki-laki dan perempuan telah mengalami perubahan dari waktu ke waktu. Hal ini dipengaruhi oleh banyak hal antara lain perkembangan ekonomi, teknologi, pendidikan dan arus global. Dalam kondisi yang demikian, maka perlu dilihat kembali bagaimana pengaturan hukum keluarga menjadi penting. Bukan saja untuk mendekatkan hukum pada realitas yang sebenarnya, tapi juga untuk memperjuangkan bahwa dalam realitas yang ada nilai-nilai keadilan senantiasa penting untuk ditegakkan.

Disadari atau tidak, segala aktivitas di dunia ini sangat dipengaruhi oleh bagaimana pola relasi dalam keluarga dibentuk. Komunitas awal sebuah masyarakat dikontruksikan dengan adanya hubungan relasi antara perempuan dan laki-laki dalam keluarga melalui

Copyright @ $\odot$ 2015, LITIGASI, p-ISSN: 0853-7100; e-ISSN: 2442-2274 
Available online at: http://ejournal.unpas.ac.id/index.php/litigasi

Litigasi, Vol. 16(1), 2015, 2658-2740

DOI: http://dx.doi.org/10.23969/litigasi.v16i1.51

lembaga hukum keluarga. Keberadaan Hukum Keluarga di Indonesia, telah diatur khususnya dalam Undang-Undang Perkawinan. Namun keberadaaan undang-undang ini selalu saja menimbulkan kontraversi, meskipun sudah 35 tahun diberlakukan. Undang-undang ini, di satu sisi dianggap sangat maju dalam konteks menata hubungan personal yang selama ini mengacu pada kebiasaan adat dan praktekpraktek agama ke dalam hukum negara yang menasional dan berlaku untuk semua. Bersamaan dengan itu, Undang-Undang Perkawinan dianggap progresif pada zamannya karena pengaturannya memberi perlindungan kepada perempuan dibandingkan praktek-praktek sebelumnya yang bersandar pada hukum kolonial, adat, agama dan kebiasaan lainnya yang cenderung semena-mena terhadap perempuan. Disisi lain, sesuai dengan perkembangan pemikiran dan gerakan hak-hak perempuan sebagai hak asasi manusia undang-undang ini dinilai masih mengandung pengaturan yang mensubordinasi perempuan dan karenanya masih diskriminatif. Dalam implementasinya, akses perempuan terhadap hak-haknya yang relatif dijamin di dalam UndangUndang Perkawinan masih jauh akibat kuatnya budaya dan praktekpraktek yang lebih bersandar pada pemahaman terhadap adat, kebiasaan dan penafsiran keagamaan ketimbang kebijakan negara. Praktek-praktek demikian masih meletakkan perempuan subordinat di wilayah domestik dan marginal di publik.

Copyright @ 2015, LITIGASI, p-ISSN: 0853-7100; e-ISSN: 2442-2274 
Available online at: http://ejournal.unpas.ac.id/index.php/litigasi

Litigasi, Vol. 16(1), 2015, 2658-2740

DOI: http://dx.doi.org/10.23969/litigasi.v16i1.51

Reformasi hukum keluarga menjadi agenda besar bagi upaya untuk memposisikan perempuan sebagai makhluk yang setara. Reformasi tidak saja dalam kebijakan negara, namun juga pada institusiinstitusi hukum, sosial dan di dalam pola pikir masyarakat yang senantiasa masih tetap mengadopsi nilai-nilai yang patriarki (mengutamakan laki-laki), meski telah ada Undang-Undang Perkawinan yang bersifat nasional, implementasi proses perkawinan tetap dilangsungkan dengan bersandar pada ajaran agama dan kepercayaan masing-masing. Pluralisme hukum masih terjadi dan tidak sepenuhnya hilang. Sebab, ada dua peradilan yang berfungsi untuk menerapkan hukum perkawinan; peradilan agama untuk mereka yang beragam islam dan peradilan umum bagi yang non Islam.

Hukum Perkawinan dan Keluarga merupakan konsentrasi yang bersifat lanjutan dan berisi asas, teori, konsep teoritik dan praktis yang menjadi ruang lingkup bidang hukum perdata materiil yang tunduk pada hukum positif dan sistem hukum Islam bagi ummat muslim.

Hukum keluarga diartikan sebagai keseluruhan ketentuan yang mengenai hubungan hukum yang bersangkutan dengan kekeluargaan sedarah dan kekeluargaan karena perkawinan (perkawinan, kekuasaan orang tua, perwalian, pengampuan, keadaan tak hadir). Kekeluargaan sedarah adalah pertalian keluarga yang terdapat antara beberapa orang yang mempunyai kekerabatan. Hukum 
Available online at: http://ejournal.unpas.ac.id/index.php/litigasi

Litigasi, Vol. 16(1), 2015, 2658-2740

DOI: http://dx.doi.org/10.23969/litigasi.v16i1.51

Keluarga dalam kaitannya dengan perkawinan adalah pertalian keluarga terjadi karena perkawinan antara seorang dengan keluarga sedarah dari istri (suaminya).

b. Polemik Pernikahan Dan Perlindungan Hukum Terhadap Perempuan

Nikah adalah akad yang menghalalkan pergaulan antara seorang laki-laki dengan perempuan yang bukan muhrim sehingga menimbulkan hak dan kewajiban antara keduanya. Menurut istilah syara' nikah itu berarti melakukan suatu akad atau perjanjian untuk mengikat diri antara seorang laki-laki dan seorang perempuan demi terwujudnya keluarga bahagia yang diridhoi oleh Allah SWT. Macam-macam nikah, yang berpotensi berpolemik dapat dibedakan menjadi (Ratna Kapoor, 1997): nikah siri, nikah kontrak (mut'ah), nikah beda agama.

1). Pernikahan siri

Fenomena nikah siri di Indonesia semakin mencuat kepermukaan dengan berbagai persoalan yang terkait di dalamnya, memunculkan ketidakadilan, tidak ada jaminan kepastian dan perlindungan hukum. Banyak kaum perempuan ditelantarkan, diceraikan, dan mengalami diskriminasi dalam rumah tangga akibat dari pernikahan siri.

Berdasarkan Islam, pernikahan disebut siri (rahasia) jika dilakukan dengan tidak memenuhi syarat dan rukun nikah menurut

Copyright @ C 2015, LITIGASI, p-ISSN: 0853-7100; e-ISSN: 2442-2274 
Available online at: http://ejournal.unpas.ac.id/index.php/litigasi

Litigasi, Vol. 16(1), 2015, 2658-2740

DOI: http://dx.doi.org/10.23969/litigasi.v16i1.51

hukum Islam. Dalam perkembangannya di masyarakat Indonesia, pernikahan siri mempunyai tiga pengertian yakni Pertama; pernikahan tanpa wali. Pernikahan semacam ini dilakukan secara rahasia (siri) dikarenakan pihak wali perempuan tidak setuju; atau karena menganggap sah pernikahan tanpa wali; atau hanya karena ingin memuaskan nafsu syahwat belaka tanpa mengindahkan lagi ketentuan-ketentuan syariat; Kedua, pernikahan yang sah secara agama (memenuhi ketentuan syarat dan rukun nikah/kawin) namun tidak dicatatkan pada kantor pegawai pencatat nikah (KUA bagi yang beragama Islam, Kantor Catatan Sipil bagi yang Non-Islam), dan Ketiga, pernikahan yang dirahasiakan karena pertimbanganpertimbangan tertentu.

Sebagian masyarakat pada tingkat pendidikan yang rendah, masih belum memandang pentingnya pencatatan pernikahan secara ke lembaga pencatat pernikahan. Akibatnya hak dan kewajiban suami - istri tidak terlindung secara hukum. Misalnya masalah kewajiban memberikan nafkah suami kepada istri, pengakuan anak secara legal ketika mengurusi kependudukan dan lain-lain. Perempuan, dalam hal ini istri siri, menjadi subjek hukum yang tidak memiliki kepastian hukum akibat dari pernikahan siri tersebut. Banyak kasus perceraian secara semena-mena yang dilakukan suami terhadap istri sirinya. Perceraian ini menimbulkan terjadinya 
Available online at: http://ejournal.unpas.ac.id/index.php/litigasi

Litigasi, Vol. 16(1), 2015, 2658-2740

DOI: http://dx.doi.org/10.23969/litigasi.v16i1.51

penelantaran dan pembiaran terhadap istri siri dan anaknya karena suami pergi tanpa kabar jelas. Selain itu, perceraian pada pernikahan siri tidak disertai pemenuhan hak atas harta bersama. Bahkan, sang istri siri kerap mengalami kekerasan. Dalam urusan administrasi kependudukan, akibat tidak diakuinya status pernikahan oleh negara, status anak dalam pernikahan siri pun menjadi kabur, dia tidak akan mendapatkan akte kelahiran yang jelas. Kondisi ini menyebabkan pihak perempuan akan sulit mendapatkan keadilan, kepastian, dan kemanfaatan hukum.

Banyak faktor yang melandasi maraknya pernikahan siri di Indonesia mulai dari ketidaktahuan masyarakat tentang pentingnya pencatatan pernikahan hingga kondisi ekonomi yang tidak mampu mencatatkan pernikahan ke KUA. Pernikahan siri juga timbul ketika sepasang kekasih tidak ingin mencatatkan pernikahannya karena takut ketahuan menikah lagi, atau dilakukan oleh pejabat PNS yang tidak ingin ketahuan berpoligami karena dilarangan oleh korsp PNS.

Intinya adalah kesadaran hukum bagi setiap warga negara untuk mentaati dan mematuhi peraturan perundang-undangan, khususnya bagi perempuan agar lebih cerdas, serta tidak lemah menghadapi bujuk rayu manisnya pernikahan tanpa legalitas agama dan negara. Upaya penyadaran kepada perempuan akan hak-hak 
Available online at: http://ejournal.unpas.ac.id/index.php/litigasi

Litigasi, Vol. 16(1), 2015, 2658-2740

DOI: http://dx.doi.org/10.23969/litigasi.v16i1.51

yang harus dimilikinya terkait peristiwa hukum dalam pernikahan juga perlu digalakkan. Informasi yang harus turut disampaikan adalah regulasi dari pemerintah yang membuat aturan yang mengikat dan tegas terkait maraknya pernikahan yang tidak memiliki bukti otentik dan payung hukum yang sesuai dengan undang-undang pernikahan Nomor 1 tahun 1987 tentang pernikahan. Dengan demikian, kasuskasus perceraian, penelantaran, pembiaran, dalam pernikahan siri yang dialami kaum perempuan-perempuan dengan status pernikahan sirih dan berbagai persoalannya dapat diminimalisir bahkan kalau memungkinkan dapat dihilangkan.

2). Kawin kontrak

Perkawinan kontrak adalah perkawinan yang berjangka waktu dan perkawinan yang memang disiapkan untuk bercerai. Sebenarnya di perkawinan ini tidak memberatkan siapapun apabila perkawinan ini tidak menghasilkan anak. Namun demikian, jika perkawinan ini menurunkan seorang anak, maka perkawinan ini merupakan bencana bagi anak tersebut dimana anak itu lambat laun akan kehilangan sebuah figur dalam dirinya yaitu figur seorang ayah, dan bukan tidak mustahil juga tidak respek terhadap ibunya.

3). Perkawinan Mut'ah

Kata nikah mut'ah berasal dari kata At-tamatu yang menurut bahasa arab mempunyai arti bersenang-senang. Kawin ini di katakan

Copyright @ $\odot$ 2015, LITIGASI, p-ISSN: 0853-7100; e-ISSN: 2442-2274 
Available online at: http://ejournal.unpas.ac.id/index.php/litigasi

Litigasi, Vol. 16(1), 2015, 2658-2740

DOI: http://dx.doi.org/10.23969/litigasi.v16i1.51

mut'ah atau bersenang-senang, karena akadnya semata-mata untuk senang-senang saja antara laki-laki perempuan dan untuk memuaskan nafsu, bukan untuk bergaul untuk sebagai suami istri, bukan untuk mendapatkan keturunan atau hidup sebagai suami istri dengan membina rumah tangga sejahtera.

Nikah mut'ah atau kawin mut'ah juga dinamakan kawin muaqqat artinya kawin untuk waktu tertentu atau kawin munqathi artinya kawin terputus yaitu seorang laki-laki mengikat perkawinan dengan perempuan untuk beberapa hari, seminggu atau sebulan.

Nikah mut'ah terjadi jika seseorang laki-laki menikahi seorang wanita dengan sesuatu dari harta untuk jangka waktu tertentu. Pernikahan ini berakhir dengan berakhirnya waktu tersebut tanpa adanya perceraian, juga tidak ada kewajiban nafkah dan tempat tinggal serta tidak ada waris-mewarisi diantara keduanya apabila salah satunya meninggal sebelum berakhirnya masa pernikahan. Pernikahan ini juga tidak mensyaratkan adanya saksi, tidak disyaratkan adanya ijin dari bapak atau wali, dan status wanitanya sama dengan wanita sewaan atau budak.

4). Perkawinan Beda Agama

Hukum pernikahan beda agama, atau biasa juga dikenal dengan pernikahan lintas agama selalu menjadi polemik yang cukup kontroversial dalam masyarakat. Persoalan yang muncul

Copyright @ C 2015, LITIGASI, p-ISSN: 0853-7100; e-ISSN: 2442-2274 
Available online at: http://ejournal.unpas.ac.id/index.php/litigasi

Litigasi, Vol. 16(1), 2015, 2658-2740

DOI: http://dx.doi.org/10.23969/litigasi.v16i1.51

adalah bolehkah seorang muslim menikahi seorang yang non muslim, dan bagaimana akibat hukumnya. Pernikahan beda agama, dapat dibedakan menjadi dua kategori berdasarkan pasangan yang menikah, yaitu (1) seorang laki-laki muslim menikahi perempuan non muslim dan sebaliknya, (2) seorang muslim perempuan yang menikahi seorang laki-laki yang non muslim. Pengkategorian ini didasarkan pada hukum di antaranya masing-masing berbeda.

5) Perkawinan Campuran

Menurut Pasal 57 Undang-Undang No. 1 Tahun 1974 tentang Perkawinan (UUP), yang dimaksud dengan perkawinan campuran adalah perkawinan antara dua orang yang di Indonesia tunduk pada hukum yang berlainan, karena perbedaan kewarganegaraan dan salah satu pihak berkewarganegaraan Indonesia. Jadi, berdasarkan ketentuan tersebut yang dimaksud dengan perkawinan campuran adalah perkawinan antara seorang Warga Negara Indonesia (WNI) dengan seorang warga negara asing (WNA).

Jika melihat ketentuan Pasal 26 ayat (1) dan ayat (3) Undang-Undang Kewarganegaraan, dapat diketahui bahwa apabila hukum negara asal si suami memberikan kewarganegaraan kepada pasangannya akibat perkawinan campuran, maka istri yang WNI dapat kehilangan kewarganegaraan Indonesia, kecuali jika dia 
Available online at: http://ejournal.unpas.ac.id/index.php/litigasi

Litigasi, Vol. 16(1), 2015, 2658-2740

DOI: http://dx.doi.org/10.23969/litigasi.v16i1.51

mengajukan pernyataan untuk tetap menjadi WNI (IIman Hadi, 2013). Status kewarganegaraan si suami yang WNA jika pasangan perkawinan campuran tersebut menetap di Indonesia, dalam ketentuan Undang-Undang Kewarganegaraan, tidak ditentukan bahwa seorang WNA yang kawin dengan WNI maka secara otomatis menjadi WNI, termasuk jika menetap di Indonesia. Hal yang perlu diperhatikan oleh si WNA selama tinggal di Indonesia adalah harus memiliki izin tinggal. WNA telah menetap tinggal di Indonesia selama 5 tahun berturut-turut atau 10 tahun berturut-turut, barulah dia memenuhi syarat mengajukan diri untuk menjadi WNI jika ia menghendaki (lihat Pasal 9 huruf $b$ Undang-Undang Kewarganegaraan).

Ketentuan tersebut di atas, Perkawinan campur yang ditentukan dalam Undang-Undang Perkawinan 1974 hanya mengatur tentang perkawinan antara WNI dan WNA, sehingga akan muncul masalah kewarganegaran. Namun, Undang-Undang Kewarganegaraan yang baru tahun 2006 ini lebih memberikan kemudahan bagi WNI dan keturunannya. Seorang WNI yang menikah dengan WNA tidak akan kehilangan kewarganegaraannya selama tidak menyatakan pindah kewarganegaraan. Anak keturunannya pun dapat memiliki kewarganegaran ganda hingga usia 18 tahun.

Copyright @ $\odot$ 2015, LITIGASI, p-ISSN: 0853-7100; e-ISSN: 2442-2274 
Available online at: http://ejournal.unpas.ac.id/index.php/litigasi

Litigasi, Vol. 16(1), 2015, 2658-2740

DOI: http://dx.doi.org/10.23969/litigasi.v16i1.51

Permasalahan lain yang muncul dari kawin campur ini adalah hak properti perempuan WNI setelah menikah dengan WNA. Akan sulit baginya untuk memiliki properti (terutama benda tidak bergerak seperti tanah dan bangunan di Indonesia) karena setelah perkawian berlangsung, semua harta menjadi harta bersama, sementara WNA tidak dapat memperoleh hak milik atas tanah di Indonesia. Oleh karena itu sebelum pernikahan dilaksanakan, disarankan kedua pasangan membuat perjanjian pranikah, terutama yang mengatur tentang harta bersama ini (Marzuki Wahid, 2009).

Perkawinan yang kewarganegaraan ganda. Mereka adalah warga negara Indonesia yang juga memiliki kewarganegaraan dari ayah atau ibunya yang merupakan warga dari negara lain. Hal tersebut tentu akan membawa dampak yang cukup signifikan terhadap kewarganegaraan keturunan tersebut, baik dari segi yuridis maupun sosiologis. Kewarganegaraan dalam arti yuridis ditandai dengan adanya ikatan hukum antara orang-orang dengan negara. Adanya ikatan hukum itu menimbulkan akibat-akibat hukum yakni, orang tersebut berada di bawah kekuasaan negara bersangkutan (akte kelahiran, hak dalam pemilu dan sebagainya). Kewarganegaraan dalam arti sosiologis tidak ditandai dengan ikatan hukum tetapi ikatan emosional seperti ikatan perasaan, ikatan keturunan, sejarah dan tanah air. Ikatan ini lahir dari penghayatan warga negara yang 
Available online at: http://ejournal.unpas.ac.id/index.php/litigasi

Litigasi, Vol. 16(1), 2015, 2658-2740

DOI: http://dx.doi.org/10.23969/litigasi.v16i1.51

bersangkutan. Kewarganegaraan juga merujuk pada segi formil dan materiil. Kewarganegaraan dalam arti formil menunjuk pada tempat kewarganegaraan. Dalam sistematika hukum, masalah kewarganegaraan berada pada hukum publik. Sementara dalam arti materiil menunjuk pada akibat hukum dari status kewarganegaraan yakni hak dan kewajiban warga negara. Selama keturunan campuran tersebut masih berumur di bawah 18 tahun, hak dan kewajiban belum terlalu diperhatikan. Namun, nanti ketika umur 18 tahun hak dan kewajiban akan menjadi lebih dipersoalkan, apalagi diumur tersebut seorang anak sudah membutuhkan surat-surat resmi sebagai aktualisasi dirinya, seperti KTP, SIM, hak untuk memilih dan sebagainya.

Sisi negatif dari anak berkewarganegaraan ganda adalah memiliki sederetan hak dan kewajiban yang lebih banyak dibanding dengan kewarganegaraan tunggal. Tertentu saja hal ini akan menimbul konflik ataupun ketimpangan yang seolah-olah mempertentangkan hak dan kewajiban tersebut.

6) Poligami Dan Akibat Hukumnya.

Undang-Undang Perkawinan menganut asas monogami sebagaimana ditentukan dalam Pasal 3 yang menyatakan bahwa, "seorang pria hanya boleh mempunyai seorang Istri dan seorang wanita hanya boleh memiliki seorang suami", namun pada bagian

Copyright @ C 2015, LITIGASI, p-ISSN: 0853-7100; e-ISSN: 2442-2274 
Available online at: http://ejournal.unpas.ac.id/index.php/litigasi

Litigasi, Vol. 16(1), 2015, 2658-2740

DOI: http://dx.doi.org/10.23969/litigasi.v16i1.51

yang lain dinyatakan bahwa dalam keadaan tertentu poligami dibenarkan (Zuhdi, 1997). Klausa kebolehan poligami di dalam Undang-Undang Perkawinan sebenarnya hanya pengecualian dan untuk itu pasal-pasalnya mencantumkan alasan-alasan yang membolehkan tersebut (Amiur Nuruddin, Azhari Akmal Tarigan, 1999). Dalam Pasal 4 dinyatakan seorang suami yang akan beristri lebih dari seorang apabila:

a. Istri tidak dapat menjalankan kewajibannya sebagai istri;

b. Istri mendapat cacat badan atau penyakit yang tidak dapat disembuhkan;

c. Istri tidak dapat melahirkan keturunan.

Adanya ketentuan pasal-pasal yang membolehkan untuk berpoligami dengan alasan-alasan tertentu, jelaslah bahwa asas yang dianut oleh Undang-Undang Perkawinan sebenarnya bukan menganut asas monogami mutlak, melainkan disebut monogami terbuka (Moh Ismail, 2013). Poligami ditempatkan pada status hukum darurat, atau dalam keadaan yang Iuar biasa. Selain itu, lembaga poligami tidak semata-mata kewenangan penuh suami, tetapi atas izin dari Hakim (pengadilan).

Syarat-syarat yang harus dipenuhi bagi seorang suami yang ingin melakukan Poligami seperti yang tercantum dalam Pasal 5 ayat 1 UUP diantaranya:

Copyright @ C 2015, LITIGASI, p-ISSN: 0853-7100; e-ISSN: 2442-2274 
Available online at: http://ejournal.unpas.ac.id/index.php/litigasi

Litigasi, Vol. 16(1), 2015, 2658-2740

DOI: http://dx.doi.org/10.23969/litigasi.v16i1.51

a. Adanya persetujuan dari istri;

b. Adanya kepastian bahwa suami mampu menjamin keperluan hidup istri-istri dan anak-anak mereka;

c. Adanya jaminan bahwa suami akan berlaku adil terhadap Istri dan anak-anak mereka.

Imbas negatif dari perkawinan poligami memungkinkan adanya penelantaran terhadap istri dan anak-anak, kekerasan fisik, kekerasan seksual, kekerasan psikis, dan kekerasan verbal. Bahkan dimungkin terjadinya kejahatan perkawinan.

\section{Pembaharuan Proses Peradilan;}

Sebelum menguraikan mengenai pembaharuan di bidang peradilan, maka terlebih dahulu penulis akan membahas mengenai advokasi. Di Indonesia ada beberapa istilah untuk attorney-at-law, istilah pertama adalah advokat yang berasal dari bahasa Belanda yaitu advocaat, dalam bahasa Inggris disebut advocate adalah person who does this professionally in a court of law, yakni seorang yang berprofesi sebagai seorang ahli hukum di Pengadilan. Bila disebut dengan seorang ahli hukum di pengadilan (professionally in a court of law) dapat saja berlaku pengertian umum yakni semua penegak hukum yang ada di pengadilan seperti hakim, jaksa, panitera, penasihat hukum adalah nota bene para pekerja hukum di pengadilan (H, A, Sukris Sarmadi, 2009).

Copyright $\odot$ 2015, LITIGASI, p-ISSN: 0853-7100; e-ISSN: 2442-2274 
Available online at: http://ejournal.unpas.ac.id/index.php/litigasi

Litigasi, Vol. 16(1), 2015, 2658-2740

DOI: http://dx.doi.org/10.23969/litigasi.v16i1.51

Istilah yang lain adalah pengacara, penasihat hukum dan konsultan hukum, sedangkan konsultan hukum biasanya tidak mewakili klien di Pengadilan. Perkataan penasihat hukum adalah perkataan yang akhir-akhir ini paling sering dipakai dalam peraturan perundang-undangan dan dianggap termasuk di dalamnya para advokat, pengacara dan konsultan hukum. Pengertian Advokat adalah, orang yang berprofesi memberi jasa hukum, baik di dalam maupun di luar pengadilan yang memenuhi persyaratan berdasarkan ketentuan Undang-Undang No. 18 Tahun 2003 tentang Advokat (Pasal 1 butir 1).

Pengertian Jasa Hukum adalah : Jasa yang diberikan Advokat berupa memberikan konsultasi hukum, bantuan hukum, menjalankan kuasa, mewakili, mendampingi, membela, dan melakukan tindakan hukum lain untuk kepentingan hukum klien (Pasal 1 butir 2 Undang-UndangNo. 18 Tahun 2003 tentang Advokat). Selain jasa hukum advokat, ada pengertian Bantuan Hukum adalah jasa hukum yang diberikan oleh Advokat secara cuma-cuma kepada klien yang tidak mampu (Pasal 1 butir 9 Undang-Undang No. 18 Tahun 2003 tentang Advokat).

Semua istilah di atas menunjuk kepada profesional hukum yang memegang gelar sarjana hukum. Hanya advokat dan pengacara yang diharuskan bersumpah yang dilaksanakan di Departemen Kehakiman atau di Pengadilan Tinggi. Karena konsultan hukum tidak perlu tampil di 
Available online at: http://ejournal.unpas.ac.id/index.php/litigasi

Litigasi, Vol. 16(1), 2015, 2658-2740

DOI: http://dx.doi.org/10.23969/litigasi.v16i1.51

pengadilan, maka mereka tidak perlu diambil sumpahnya (Ali Budiardjo, dan Nugroho Reksodiputro, 2002).

Di Indonesia ada beberapa asosiasi profesi hukum. Advokat dan pengacara mempunyai Peradin (Persatuan Advokat Indonesia), Ikadin (Ikatan Advokat Indonesia), AAI (Asosiasi Advokat Indonesia) dan IPHI (Ikatan Penasihat Hukum Indonesia). Konsultan hukum mempunyai AKHI (Asosiasi Konsultan Hukum Indonesia). Asosiasi profesi lainnya ialah Persahi (Perhimpunan Sarjana Hukum Indonesia) yang keanggotaannya terbuka bagi semua lulusan fakultas hukum (praktisi hukum, penasihat hukum perusahaan, sarjana hukum yang bekerja dalam pemerintahan, dosen hukum, hakim dan jaksa). Ikahi (Ikatan Hakim Indonesia) anggotanya khusus hakim dan Persaja (Persatuan Jaksa) khusus buat Jaksa. Setiap asosiasi profesi ini mempunyai peraturan dan ketentuannya sendiri. Sebagai contoh, Ikadin mempunyai peraturan yang disebut Kode Etik Advokat Indonesia (Ali Budiardjo dan Nugroho Reksodiputro, 2002).

Ketentuan yang berkaitan dengan masalah bantuan hukum. Salah satu asas hukum acara pidana yang penting adalah bahwa setiap orang yang tersangkut perkara wajib diberi kesempatan memperoleh bantuan hukum yang semata-mata diberikan untuk melaksanakan kepentingan pembelaan atas dirinya. Asas tersebut selanjutnya dijabarkan dalam ketentuan-ketentuan yang terdapat dalam KUHAP khususnya pada Bab VII tentang Bantuan Hukum (Pasal 69 sampai dengan Pasal 74). 
Available online at: http://ejournal.unpas.ac.id/index.php/litigasi

Litigasi, Vol. 16(1), 2015, 2658-2740

DOI: http://dx.doi.org/10.23969/litigasi.v16i1.51

Ketentuan-ketentuan tersebut terkait erat dengan ketentuan mengenai tersangka dan terdakwa, karena salah satu hak yang dimiliki tersangka dan terdakwa adalah hak untuk memperoleh bantuan hukum atau hak untuk didampingi penasihat hukum (Al, Wisnubroto dan G, Widiartana, 2005).

Hal ini telah menjadi ketentuan universal di negara-negara demokrasi dan beradab. Dalam The International Covenant an Civil and Political Right article 14 sub 3d kepada tersangka/terdakwa diberikan jaminan berikut :

To be tried in his presence of his own choosing, to be inform, if he does not have legal assistance, of this right, and to have legal assistance assigneg to him, in any case where the interests justice so require, and without payment by him in any such case if he does not have sufficient means to pay for it.

(diadili dengan kehadiran terdakwa, membela diri sendiri secara pribadi atau dengan bantuan penasihat hukum menurut pilihannya sendiri, diberi tahu tentang hak-haknya ini jika ia tidak mempunyai penasihat hukum dan ditunjuk penasihat hukum untuk dia jika untuk kepentingan peradilan perlu untuk itu, dan jika ia tidak mampu membayar penasihat hukum ia dibebaskan dari pembayaran) (Andi Hamzah, 2010).

Menurut Pasal 69 sampai dengan 74 KUHAP, tersangka/terdakwa mendapat kebebasan yang sangat luas, antara lain meliputi:

1. Bantuan hukum dapat diberikan sejak saat tersangka ditangkap atau ditahan.

2. Bantuan hukum dapat diberikan pada semua tingkat pemeriksaan.

3. Penasihat hukum dapat menghubungi tersangka/terdakwa pada semua tingkat pemeriksaan pada setiap saat.

Copyright @ $\odot$ 2015, LITIGASI, p-ISSN: 0853-7100; e-ISSN: 2442-2274 
Available online at: http://ejournal.unpas.ac.id/index.php/litigasi

Litigasi, Vol. 16(1), 2015, 2658-2740

DOI: http://dx.doi.org/10.23969/litigasi.v16i1.51

4. Pembicaraan antara penasihat hukum dan tersangka tidak didengar oleh penyidik dan penuntut umum kecuali pada delik yang menyangkut keamanan Negara.

5. Turunan berita acara diberikan kepada tersangka atau penasihat hukum guna kepentingan pembelaan.

6. Penasihat hukum berhak mengirim dan menerima surat dari tersangka/terdakwa.

Beberapa catatan ketentuan KUHAP yang berkaitan dengan Bantuan Hukum, antara lain :

1). Kewajiban Negara dalam Menyediakan Bantuan Hukum.

Kewajiban negara untuk memberikan bantuan hukum khususnya kepada mereka yang tidak mampu merupakan bagian yang sangat mendasar karena memiliki landasan yang kuat mulai dari konstitusinya hingga berbagai instrumen internasional. Konstitusi Indonesia yang dijadikan landasan bantuan hukum misalnya Pasal 28D ayat (1) UUD 1945 yang menyatakan bahwa: "Setiap orang berhak atas pengakuan, jaminan, perlindungan, dan kepastian hukum yang adil serta perlakuan yang sama dihadapan hukum". Selanjutnya, Pasal 28 I ayat (4) UUD 1954 menyatakan bahwa : "Perlindungan, pemajuan, penegakan, dan pemenuhan hak asasi manusia adalah tanggung jawab negara, terutama pemerintah".

Copyright @ $\odot$ 2015, LITIGASI, p-ISSN: 0853-7100; e-ISSN: 2442-2274 
Available online at: http://ejournal.unpas.ac.id/index.php/litigasi

Litigasi, Vol. 16(1), 2015, 2658-2740

DOI: http://dx.doi.org/10.23969/litigasi.v16i1.51

Ketentuan ini mengamanatkan bahwa, pemberian bantuan hukum merupakan hak setiap warga negara yang harus dijamin dan difasilitasi oleh pemerintah. Beberapa Instrumen Internasional menunjukan bahwa, hak setiap orang mendapatkan bantuan hukum dan kewajiban negara untuk memberikan bantuan hukum bukan sematamata khas Indonesia, melainkan merupakan prinsip universal. Sebagai contoh, berikut ini kutipan salah satu rumusan yang relevan. Misalnya dalam Article 3.23 World Conference on the Independence of Justice c.q. Universal Declaration on the Independence of justice yang menyatakan: "Government shall be responsible for providing sufficient funding for legal service programmes for the poor". Sesuatu yang sering dipersoalkan adalah fenomena proses pemeriksaan perkara pidana yang banyak diantaranya tidak terdapat pendampingan penasehat hukum (Al, Wisnubroto dan G, Widiartana, 2005).

Pasal 56 KUHAP mewajibkan penunjukan penasihat hukum bagi tersangka/terdakwa yang tidak memiliki penasehat hukum, terbatas pada 2 (dua) kriteria :

a. Semua tersangka/terdakwa yang disangka/didakwa melakukan tindak pidana yang diancam dengan hukuman mati, hukuman seumur hidup, atau hukuman penjara 15 (lima belas) tahun atau lebih.

b. Tersangka/terdakwa yang tidak mampu yang diancam hukuman penjara 5 (lima) tahun atau lebih.

Copyright @ C 2015, LITIGASI, p-ISSN: 0853-7100; e-ISSN: 2442-2274 
Available online at: http://ejournal.unpas.ac.id/index.php/litigasi

Litigasi, Vol. 16(1), 2015, 2658-2740

DOI: http://dx.doi.org/10.23969/litigasi.v16i1.51

Dengan demikian, fasilitas bantuan hukum dari negara (melalui prosedur penunjukan penasihat hukum) tidak bersifat wajib bagi semua tersangka/terdakwa yang tergolong mampu dan disangka/didakwa melakukan tindak pidana yang diancam hukuman di bawah 15 (lima belas) tahun penjara atau tersangka-terdakwa yang tidak mampu yang diancam hukuman 5 (lima) tahun penjara.

Sekalipun demikian khusus untuk perkara pidana, tersangka atau terdakwanya anak atau wanita hendaknya mendapat perhatian khusus yang dikecualikan dari pembatasan Pasal 56 KUHAP. Jika dikembalikan pada komitmen bantuan lebih ditujukan pada kaum yang diposisikan lemah, KUHAP mestinya mengatur bahwa semua kasus yang tersangka atau terdakwanya wanita atau anak wajib didampingi oleh penasihat hukum (Al, Wisnubroto dan G, Widiartana, 2005).

2). Siapa yang Dimaksud Penasihat Hukum.

Pasal 1 butir 13 KUHAP memberikan pengertian bahwa yang dimaksud dengan penasihat hukum adalah, seorang yang memenuhi syarat yang ditentukan oleh atau berdasar undang-undang untuk memberi bantuan hukum. Di Indonesia terdapat banyak istilah/sebutan untuk sebutan terhadap pengemban profesi di bidang bantuan hukum. Keanekaragaman sebutan antara lain : advokat, penasihat hukum, pengacara atau pengacara praktek.

Copyright $\odot$ 2015, LITIGASI, p-ISSN: 0853-7100; e-ISSN: 2442-2274 
Available online at: http://ejournal.unpas.ac.id/index.php/litigasi

Litigasi, Vol. 16(1), 2015, 2658-2740

DOI: http://dx.doi.org/10.23969/litigasi.v16i1.51

3). Kebabasan Hubungan antara Penasihat Hukum dan Tersangka/Terdakwa.

KUHAP menjamin kebebasan hubungan antara penasihat hukum dan tersangka/terdakwa. Namun kebebasan tersebut dibatasi apabila penasihat dan atau tersangka menyalahgunakan kebebasan tersebut (Pasal 70 ayat $(2,3,4)$ dan Pasal 71 KUHAP).

4). Bantuan Hukum untuk Pihak Saksi/Korban.

KUHAP sendiri dinilai terlalu mengakomodasi hak-hak tersangka dan terdakwa terutama yang berkaitan dengan hak untuk memperoleh bantuan hukum, sedangkan untuk saksi khususnya saksi korban tidak ada ketentuan tentang hal tersebut. Lemahnya posisi saksi dan korban sering kali justru dimanfaatkan oleh pejabat peradilan sematamata untuk mencapai target pemeriksaan tanpa mempedulikan hak dan kepentingan, sehingga perlu diadvokasi oleh pihak di luar pejabat resmi peradilan.

5). Penyesuaian dengan Undang-Undang Advokat.

Setelah diundangkannya Undang-Undang No. 18 Tahun 2003 tentang Advokat, maka ketentuan dalam KUHAP yang berkaitan dengan bantuan hukum dan keberadaan penasihat hukum, harus diharmonisasikan dengan undang - undang tersebut. Hal ini perlu

Copyright @ $\odot$ 2015, LITIGASI, p-ISSN: 0853-7100; e-ISSN: 2442-2274 
Available online at: http://ejournal.unpas.ac.id/index.php/litigasi

Litigasi, Vol. 16(1), 2015, 2658-2740

DOI: http://dx.doi.org/10.23969/litigasi.v16i1.51

dilakukan karena Undang-Undang Advokat dapat dikatakan sebagai aturan hukum yang khusus jika dihadapkan dengan ketentuan mengenai bantuan hukum dalam KUHAP sebagai ketentuan umum (AI, Wisnubroto dan G, Widiartana, 2005).

Usaha mewujudkan prinsip-prinsip negara hukum dalam kehidupan bermasyarakat dan bernegara, peran dan fungsi Advokat sebagai profesi yang bebas, mandiri dan bertanggung jawab merupakan hal yang penting, juga lembaga peradilan dan instansi penegak hukum seperti kepolisian dan kejaksaan. Melalui jasa hukum yang diberikan, Advokat menjalankan tugas profesinya demi tegaknya keadilan berdasarkan hukum untuk kepentingan masyarakat pencari keadilan, termasuk usaha memberdayakan masyarakat dalam menyadari hak-hak fundamental mereka di depan hukum.

Advokat sebagai salah satu unsur sistem peradilan merupakan salah satu pilar dalam menegakkan supremasi hukum dan hak asasi manusia. Selain dalam proses peradilan, peran Advokat juga terlihat di jalur profesi di luar pengadilan. Kebutuhan terhadap jasa hukum Advokat di luar proses peradilan pada saat sekarang semakin meningkat, sejalan dengan semakin berkembangnya kebutuhan hukum masyarakat terutama dalam memasuki kehidupan yang semakin terbuka dalam pergaulan antar bangsa. Melalui pemberian jasa 
Available online at: http://ejournal.unpas.ac.id/index.php/litigasi

Litigasi, Vol. 16(1), 2015, 2658-2740

DOI: http://dx.doi.org/10.23969/litigasi.v16i1.51

konsultasi, negosiasi maupun dalam pembuatan kontrak-kontrak dagang, profesi Advokat ikut memberi sumbangan berarti bagi pemberdayaan masyarakat serta pembaharuan hukum nasional khususnya di bidang ekonomi dan perdagangan, termasuk dalam penyelesaian sengketa di luar pengadilan.

Terdapat organisasi lain yang juga menangani masalah hukum dalam masyarakat. Pertama, adalah bantuan hukum, kedua adalah pejabat pembuat akta tanah (PPAT), ketiga adalah konsultan pajak, dan keempat adalah pusat bantuan umum (serikat buruh, lembaga perlindungan konsumen, organisasi perempuan, dan seterusnya). Meskipun pemerintah juga menjalankan program bantuan idin yang disalurkan kepada pengacara melalui pengadilan, dan program konsultasi idin melalui fakultas idin universitas negeri, pola bantuan idin yang paling mengesankan adalah yang dijalankan oleh iding swasta.

Bantuan idin mempunyai sejarah yang panjang dengan profesi idin, yaitu dengan asosiasi advokat Indonesia pada permulaan tahun 1960 (dahulu Peradin) dimana mereka memberikan jasa bantuan idin secara gratis pada pengadilan untuk perkara iding I bagi warga iding yang kurang mampu, dengan menunjuk salah satu anggota mereka untuk mewakili klien di pengadilan (Ali Budiardjo dan Nugroho Reksodiputro kerja sama dengan Mochtar, Karuwin \& Komar, 2002).

Copyright $\odot$ 2015, LITIGASI, p-ISSN: 0853-7100; e-ISSN: 2442-2274 
Available online at: http://ejournal.unpas.ac.id/index.php/litigasi

Litigasi, Vol. 16(1), 2015, 2658-2740

DOI: http://dx.doi.org/10.23969/litigasi.v16i1.51

6). Hak dan Kewajiban Advokat.

Sebagaimana tercantum dalam Undang-Undang No. 18 Tahun 2003 tentang Advokat :

1. Advokat bebas mengeluarkan pendapat atau pernyataan dalam membela perkara yang menjadi tanggung jawabnya di dalam iding pengadilan dengan tetap berpegang pada kode etik profesi dan peraturan perundang-undangan (Pasal 14).

2. Advokat bebas dalam menjalankan tugas profesinya untuk membela perkara yang menjadi tanggung jawabnya dengan tetap berpegang pada kode etik profesi dan peraturan perundang- undangan (Pasal 15).

3. Advokat tidak dapat dituntut baik secara perdata maupun pidana dalam menjalankan tugas profesinya dengan iktikad baik untuk kepentingan pembelaan Klien dalam sidang pengadilan (Pasal 16).

4. Dalam menjalankan profesinya, Advokat berhak memperoleh informasi, data, dan dokumen lainnya, baik dari instansi Pemerintah maupun pihak lain yang berkaitan dengan kepentingan tersebut yang diperlukan untuk pembelaan kepentingan Kliennya sesuai dengan peraturan perundang-undangan (Pasal 17).

5. a) Advokat dalam menjalankan tugas profesinya dilarang membedakan perlakuan terhadap Klien berdasarkan jenis kelamin, agama, politik, keturunan, ras, atau latar belakang sosial dan

Copyright @ C 2015, LITIGASI, p-ISSN: 0853-7100; e-ISSN: 2442-2274 
Available online at: http://ejournal.unpas.ac.id/index.php/litigasi

Litigasi, Vol. 16(1), 2015, 2658-2740

DOI: http://dx.doi.org/10.23969/litigasi.v16i1.51

budaya.

b) Advokat tidak dapat diidentikkan dengan Kliennya dalam membela perkara Klien oleh pihak yang berwenang dan/atau masyarakat (Pasal 18).

6. a) Advokat wajib merahasiakan segala sesuatu yang diketahui atau diperoleh dari Kliennya karena hubungan profesinya, kecuali ditentukan lain oleh undang-undang.

b) Advokat berhak atas kerahasiaan hubungannya dengan Klien, termasuk perlindungan atas berkas dan dokumennya terhadap penyitaan atau pemeriksaan dan perlindungan terhadap penyadapan atas komunikasi elektronik Advokat (Pasal 19).

7. a) Advokat dilarang memegang jabatan lain yang bertentangan dengan kepentingan tugas dan martabat profesinya.

b) Advokat dilarang memegang jabatan lain yang meminta pengabdian sedemikian rupa sehingga merugikan profesi Advokat atau mengurangi kebebasan dan kemerdekaan dalam menjalankan tugas profesinya.

c) Advokat yang menjadi pejabat negara, tidak melaksanakan tugas profesi Advokat selama memangku jabatan tersebut (Pasal 20).

Dalam Bagian Keempat Pasal 6 Undang-Undang No. 18 Tahun 2003 tentang Advokat, menyatakan bahwa advokat dapat dikenai tindakan dengan alasan:

Copyright $\odot$ 2015, LITIGASI, p-ISSN: 0853-7100; e-ISSN: 2442-2274 
Available online at: http://ejournal.unpas.ac.id/index.php/litigasi

Litigasi, Vol. 16(1), 2015, 2658-2740

DOI: http://dx.doi.org/10.23969/litigasi.v16i1.51

a. mengabaikan atau menelantarkan kepentingan kliennya;

b. berbuat atau bertingkah laku yang tidak patut terhadap lawan atau rekan seprofesinya;

c. bersikap, bertingkah laku, bertutur kata, atau mengeluarkan pernyataan yang menunjukkan sikap tidak hormat terhadap hukum, peraturan perundang-undangan, atau pengadilan;

d. berbuat hal-hal yang bertentangan dengan kewajiban, kehormatan, atau harkat dan martabat profesinya;

e. melakukan pelanggaran terhadap peraturan perundang-undangan dan atau perbuatan tercela;

f. melanggar sumpah/janji Advokat dan/atau kode etik profesi Advokat.

Adapun yang dimaksud dengan Advokasi adalah : suatu cara untuk mencapai tujuan tertentu, lebih rinci advokasi merupakan suatu usaha yang sistematik dan terorganisir untuk mempengaruhi dan mendesakkan terjadinya perubahan kebijakan publik secara bertahapmaju, melalui semua saluran dan piranti demokrasi perwakilan, prosesproses politik dan legislasi dalam sistem yang berlaku.

Aktivitas advokasi dahulu hanya dilakukan oleh kaum aktivis atau elit politik, namun dalam paradigma baru tentang advokasi untuk keadilan sosial, advokasi justru meletakkan korban kebijakan sebagai subyek utama. Sedangkan aktivis ataupun sebuah lembaga advokasi 
Available online at: http://ejournal.unpas.ac.id/index.php/litigasi

Litigasi, Vol. 16(1), 2015, 2658-2740

DOI: http://dx.doi.org/10.23969/litigasi.v16i1.51

hanya sebagai pengantar atau penghubung antar berbagai unsur progresif dalam masyarakat, melalui terbentuknya aliansi-aliansi strategis yang memperjuangkan terciptanya keadilan sosial.

Perlu dilakukan advokasi, dikarenakan seringkali suatu kebijakan keluar tanpa mempertimbangkan kebutuhan dan atau rasa keadilan masyarakat, atau suatu proses tidak berjalan sebagaimana mestinya, sedangkan pembuat dan atau pelaksana kebijakan tidak merasa perlu melakukan perubahan kearah positif-maju. Sehingga masyarakat sebagai subyek pembangunan harus mau dan mampu mendesakkan perubahan tersebut.

Sistem peradilan Indonesia terbagi ke dalam empat jurisdiksi yaitu, peradilan umum, peradilan tata usaha negara, peradilan militer dan peradilan agama (Islam). Dua jurisdiksi pertama yang disebutkan, pembinaan administratifnya dilakukan oleh Departemen Kehakiman, sementara dua jurisdiksi yang disebutkan terakhir pembinaan administratifnya oleh masing-masing departemen, yakni Departemen Pertahanan dan Keamanan, serta Departemen Agama. Perlu ditambah pula, pembentukan dua peradilan yang disebutkan terakhir hanya di daerah tertentu, dan bahwa peradilan agama terutama melaksanakan hukum Islam (Ali Budiardjo dan Nugroho Reksodiputro kerja sama dengan Mochtar, Karuwin \& Komar, 2002).

Copyright @ C 2015, LITIGASI, p-ISSN: 0853-7100; e-ISSN: 2442-2274 
Available online at: http://ejournal.unpas.ac.id/index.php/litigasi

Litigasi, Vol. 16(1), 2015, 2658-2740

DOI: http://dx.doi.org/10.23969/litigasi.v16i1.51

Empat lingkungan peradilan tersebut sebenarnya terdiri dari lingkungan peradilan umum dan lingkungan peradilan khusus. Perbedaan antara peradilan umum dan peradilan khusus terletak pada perkara-perkara dan dan golongan rakyat tertentu. Peradilan khusus mengadili perkara-perkara golongan tertentu yakni : Peradilan Agama untuk perkara-perkara tentang hukum perkawinan, kewarisan, hibah, wakaf dan wasiat. Dengan hadirnya Undang-Undang No. 3 Tahun 2006 tentang Peradilan Agama perkara yang ditangani oleh Pengadilan Agama lebih luas menyangkut ekonomi syariah.

Peradilan umum adalah peradilan bagi rakyat pada umumnya, baik mengenai perkara perdata maupun perkara pidana. Peradilan umum ini ialah Pengadilan Negeri, Pengadilan Tinggi, dan Mahkamah Agung. Dalam peradilan umum dapat diadakan pengkhususan lagi, berupa Pengadilan Lalu lintas (Tilang), Pengadilan Anak-anak, Pengadilan Ekonomi. Kemudian berdasarkan Pasal 15 ayat (1) UndangUndang No. 4 Tahun 2004 tentang Kekuasaan Kehakiman, dalam penjelasannya disebutkan tentang "pengadilan khusus" dalam ketentuan ini adalah pengadilan anak, pengadilan niaga, pengadilan hak asasi manusia, pengadilan tindak pidana korupsi, pengadilan hubungan industrial yang berada di lingkungan peradilan umum, dan pengadilan pajak di lingkungan peradilan tata usaha Negara $(H, A$, Sukris Sarmadi, 2009).

Copyright @ C 2015, LITIGASI, p-ISSN: 0853-7100; e-ISSN: 2442-2274 
Available online at: http://ejournal.unpas.ac.id/index.php/litigasi

Litigasi, Vol. 16(1), 2015, 2658-2740

DOI: http://dx.doi.org/10.23969/litigasi.v16i1.51

7). Proses Peradilan di Indonesia :

1. Proses Litigasi

Proses litigasi adalah suatu proses penyelesaian hukum melalui jalur peradilan, baik melalui peradilan umum, peradilan agama, atau peradilan administrasi negara dan lain sebagainya. Proses litigasi yang berlaku di Indonesia diatur di dalam berbagai peraturan perundang-undangan, termasuk proses litigasi yang ditempuh bagi kasus kekerasan dalam rumah tangga.

Proses litigasi yang berlaku untuk kasus kekerasan dalam rumah tangga dapat dilakukan memalui jalur hukum pidana dan dapat juga melalui jalur hukum perdata, dan untuk penyelesaian melalui jalur pidana tidak membedakaan apakah pelakunya wanita (istri) atau laki-laki (suami). Proses penyelesaiannya menggunakan hukum acara pidana (KUHAP), hanya yang menjadi perbedaan kasus KDRT dengan kasus pidana umumnya adalah bahwa kasus KDRT merupakan kasus yang masuk ke dalam jenis delik aduan, yaitu suatu delik atau tindak pidana yang baru menjadi suatu tindak pidana apabila korban tindak pidana tersebut merasa dirugikan dan mengadukan perbuatan pelaku ke kepolisian sebagai aparat penegak hukum, dan pada saat korban mengadukan ke kepolisian, maka pada saat itulah polisi harus menggunakan hukum acara yang berlaku, yaitu KUHAP.

Copyright @ C 2015, LITIGASI, p-ISSN: 0853-7100; e-ISSN: 2442-2274 
Available online at: http://ejournal.unpas.ac.id/index.php/litigasi

Litigasi, Vol. 16(1), 2015, 2658-2740

DOI: http://dx.doi.org/10.23969/litigasi.v16i1.51

KUHAP diberlakukan untuk melaksanakan tatacara peradilan dalam lingkungan peradilan umum pada semua tingkat peradilan. Lingkup dari pelaksanaan tata cara peradilan diantaranya Penyidik dan Penuntut Umum. Penyidik adalah setiap pejabat polisi negara Republik Indonesia dan pejabat pegawai negeri sipil tertentu yang diberi wewenang khusus oleh undang-undang, wewenang tersebut menurut Pasal 5 KUHAP adalah :

a. Menerima laporan atau pengaduan dari seseorang tentang adanya tindak pidana.

b. Mencari keterangan dan barang bukti.

c. Menyuruh berhenti seorang yang dicurigai dan menanyakan serta memeriksa tanda pengenal diri.

d. Mengadakan tindakan lain menurut hukum yang bertanggung jawab.

Atas perintah penyidik dapat dilakukan tindakan berupa penangkapan, larangan meninggalkan tempat, penggeladahan, penyitaan, pemeriksaan, penyitaan surat, pengambilan sidik jari, membawa dan menghadapkan seorang pada penyidik.

Penuntut umum adalah jaksa yang diberi wewenang oleh undang-undang untuk melakukan penuntutan dan melaksanakan penetapan hakim, mempunyai wewenang sebagaimana tercantum dalam Pasal 14 KUHAP :

Copyright @ C 2015, LITIGASI, p-ISSN: 0853-7100; e-ISSN: 2442-2274 
Available online at: http://ejournal.unpas.ac.id/index.php/litigasi

Litigasi, Vol. 16(1), 2015, 2658-2740

DOI: http://dx.doi.org/10.23969/litigasi.v16i1.51

a. Menerima dan memeriksa berkas perkara penyidikan dari penyidik atau penyidik pembantu;

b. Mengadakan prapenuntutan apabila ada kekurangan pada penyidikan, dengan memperhatikan ketentuan Pasal 110 ayat (3) dan ayat (4), dengan memberi petunjuk dalam rangka penyempurnaan penyidikan dari penyidik;

c. Memberi perpanjangan penahanan, melakukan penahanan atau penahanan lanjutan dan atau mengubah status tahanan setelah perkaranya dilimpahkan oleh penyidik;

d. Membuat surat dakwaan;

e. Melimpahkan perkara ke pengadilan;

f. Menyampaikan pemberitahuan kepada terdakwa tentang ketentuan hari dan waktu perkara disidangkan yang disertai surat panggilan, baik kepada terdakwa maupun saksi, untuk datang pada sidang yang telah ditentukan;

g. Melakukan penuntutan;

h. Menutup perkara demi kepentingan idin;

i. Mengadakan tindakan lain dalam lingkup tugas dan tanggung jawab sebagai penuntut umum menurut ketentuan UndangUndang ini;

j. Melaksanakan penetapan hakim. 
Available online at: http://ejournal.unpas.ac.id/index.php/litigasi

Litigasi, Vol. 16(1), 2015, 2658-2740

DOI: http://dx.doi.org/10.23969/litigasi.v16i1.51

Selain penyidik dan penuntut umum yang menjadi idin dalam beracara di peradilan pidana yaitu adanya tersangka dan terdakwa. Tersangka adalah seorang yang karena perbuatannya atau keadaannya, berdasarkan bukti permulaan patut diduga sebagai pelaku tindak pidana (Pasal 1 angka 14 KUHAP). Terdakwa adalah seorang tersangka yang dituntut, diperiksa dan diadili di iding pengadilan (Pasal 1 angka 15 KUHAP).

Menurut Pasal 50 KUHAP, tersangka dan terdakwa mempunyai hak :

1) Berhak segera mendapatkan pemeriksaan oleh penyidik dan selanjutnya dapat diajukan kepada penuntut umum;

2) Berhak perkaranya segera dimajukan ke pengadilan oleh penuntut umum;

3) Berhak segera diadili oleh pengadilan.

Terhadap pemeriksaan pada tingkat penyidikan sampai tingkat pengadilan, tersangka atau terdakwa berhak memberikan keterangan secara bebas kepada penyidik atau hakim. Guna kepentingan pembelaan, tersangka atau terdakwa berhak mendapat bantuan hukum dari seorang atau lebih penasihat hukum selama dalam waktu dan pada setiap tingkat pemeriksaan, menurut tatacara yang ditentukan dalam undang-undang. Untuk mendapatkan penasihat hukum tersebut, tersangka atau terdakwa berhak memilih 
Available online at: http://ejournal.unpas.ac.id/index.php/litigasi

Litigasi, Vol. 16(1), 2015, 2658-2740

DOI: http://dx.doi.org/10.23969/litigasi.v16i1.51

sendiri penasihat hukumnya. Terdakwa berhak untuk diadili di sidang pengadilan yang terbuka untuk umum. Tersangka atau terdakwa berhak menuntut ganti kerugian dan rehabilitasi sebagaimana diatur dalam Pasal 95 KUHAP.

Selain proses hukum acara pidana yang dapat dilalui, proses litigasi yang dapat ditempuh di dalam kasus kekerasan dalam rumah tangga, adalah proses hukum acara perdata melalui proses gugatan yang dilakukan baik oleh pelaku ataupun oleh korban (istri atau suami). Pendampingan yang dapat dilakukan di dalam proses hukum acara perdata sudah dapat dilakukan pada saat proses gugatan diajukan ke pengadilan (Pengadilan Negeri untuk non muslim) dan (Pengadilan Agama untuk muslim), dan proses pendampingan harus diberikan oleh negara kepada para pihak sampai proses hukum acara perdata selesai dilakukan, dan ini dilakukan sebagai kewajiban negara untuk memberikan bantuan hukum bagi para pihak.

2. Proses Non Litigasi

Suatu proses penyelesaian dalam bidang peradilan yang berupa penyelesaian yang dilakukan di luar pengadilan, proses ini dilakukan melalui : Negosiasi, Mediasi, Konsiliasi, dan Arbitrase. Proses penyelesaian sengketa ini telah dilembagakan melalui 
Available online at: http://ejournal.unpas.ac.id/index.php/litigasi

Litigasi, Vol. 16(1), 2015, 2658-2740

DOI: http://dx.doi.org/10.23969/litigasi.v16i1.51

Undang-Undang No. 30 Tahun 1999 tentang Arbitrase dan Alternatif Penyelesaian Sengketa.

Keunggulan dari penyelesaian sengketa secara nonlitigasi dapat diidentifikasi sebagai berikut :

a. Sifat kesukarelaan dalam proses.

b. Prosedur cepat.

c. Putusan nonyudisial.

d. Prosedur rahasia (confidential).

e. Fleksibilitas dalam merancang syarat-syarat penyelesaian masalah.

f. Hemat waktu dan biaya.

g. Pemeliharaan hubungan baik.

h. Lebih mudah dikontrol dan lebih mudah memperkirakan hasil.

i. Putusan cenderung bertahan lama karena penyelesaian sengketa secara kooperatif dibandingkan pendekatan adversial atau pertentangan.

Hakikatnya putusan lembaga penyelesaian sengketa alternatif sebagaimana tersebut di atas adalah kesepakatan dari para pihak bersengketa yang bersifat win-win solution. Konsekuensi logis dari putusan yang demikian adalah pelaksanaannya juga akan berlangsung secara sukarela dan meminimalisasi konflik di belakang hari.

Copyright @ 2015 , LITIGASI, p-ISSN: 0853-7100; e-ISSN: 2442-2274 
Available online at: http://ejournal.unpas.ac.id/index.php/litigasi

Litigasi, Vol. 16(1), 2015, 2658-2740

DOI: http://dx.doi.org/10.23969/litigasi.v16i1.51

Beberapa alasan mengapa alternatif penyelesaian sengketa mulai mendapat perhatian di Indonesia, yaitu :

1) Faktor ekonomis, alternatif penyelesaian sengketa memilik potensi sebagai sarana untuk menyelesaikan sengketa yang lebih ekonomis, baik dari sudut pandang biaya maupun waktu yang diperlukan.

2) Faktor ruang lingkup yang dibahas, alternatif penyelesaian sengketa memiliki kemampuan untuk membahas agenda permasalahan secara lebih luas, komprehensif, dan fleksibel.

3) Faktor pembinaan hubungan baik, alternatif penyelesaian sengketa yang mengadalkan cara-cara penyelesaian yang kooperatif sangat cocok bagi mereka yang menekankan pentingnya hubungan baik antarmanusia, yang telah berlangsung ataupun yang akan datang.

Analisis dari Pembaharuan Hukum adalah bahwa pembaharuan hukum pada hakikatnya mengandung makna, suatu upaya untuk melakukan reorientasi dan reformasi hukum yang sesuai dengan nilai-nilai sentral sosio politik, sosio filosofik dan sosiu kultural masyarakat Indonesia yang melandasi kebijakan sosial, kebijakan kriminal dan kebijakan penegakan hukum di Indonesia (Barda Nawawi Arief, 1996). Pembaharuan Hukum menuntut adanya pembaharuan ideologi hukum yaitu sistem nilai yang 
Available online at: http://ejournal.unpas.ac.id/index.php/litigasi

Litigasi, Vol. 16(1), 2015, 2658-2740

DOI: http://dx.doi.org/10.23969/litigasi.v16i1.51

dijadikan spirit dalam perangkat hukum tersebut. Pembaharuan hukum juga berkorelasi dengan ideologi penegak hukum, karena legitimasi hukum dapat muncul dari praktek penerapan hukum karena legitimasi hukum dapat muncul dari praktek penerapan hukum.

Istilah "pembaharuan hukum" sebenarnya mengadung makna yang luas mencakup sistem hukum. Menurut Friedman (Lawrence M, Friedman, 1994), sistem hukum terdiri atas struktur hukum (structure), substansi / materi hukum (substance), dan budaya hukum (legal culture), sehingga, bicara pembaharuan hukum maka pembaharuan yang dimaksud adalah pembaharuan sistem hukum secara keseluruhan.

Kaitannya dengan pembentukan hukum di Indonesia, didasari dengan pertimbangan tujuan hukum yaitu keadilan, selain kepastian hukum dan kemanfaatan. Keadilan ini berkaitan dengan pendistribusian hak dan kewajiban, diantara sekian hak yang dimiliki manusia secara alamiah, yaitu hak asasi manusia atau hak kodrati manusia, semua manusia tanpa pembedaan ras, suku, bangsa, agama, berhak mendapatkan keadilan.

Berdasarkan sistem hukum modern, pola pendistribusian hak dan kewajiban itu harus dituangkan sebagai suatu kesepakatan sosial. Dalam konteks ini, Thomas Hobbes melalui teori kontrak 
Available online at: http://ejournal.unpas.ac.id/index.php/litigasi

Litigasi, Vol. 16(1), 2015, 2658-2740

DOI: http://dx.doi.org/10.23969/litigasi.v16i1.51

sosialnya, berjasa untuk menjelaskan filosofi mendasar tentang peranan penting negara. Namun, seiring dengan makin menguatnya peran-peran masyarakat sipil (civil society), kesepakatankesepakatan itu tidak harus berada di bawah payung kekuasan negara. Oleh sebab itu, kesepakatan tersebut dapat berwujud undang - undang, konvensi, anggaran dasar, kode etik, dan sebagainya (Shidarta, 2010). Sejak reformasi bergulir di Indonesia para elit politik atau tokoh-tokoh bangsa telah bersepakat bahwa sistem politik Indonesia harus dibangun atas dasar prinsip-prinsip demokrasi yang tulen (genuine) yang memenuhi kriteria menurut teori demokrasi dalam ilmu politik. Gerakan reformasi juga meneguhkan kembali tekad untuk membangun Indonesia sebagai negara hukum, (the rule of law. Rechtsstaat). 
Available online at: http://ejournal.unpas.ac.id/index.php/litigasi

Litigasi, Vol. 16(1), 2015, 2658-2740

DOI: http://dx.doi.org/10.23969/litigasi.v16i1.51

\section{SIMPULAN DAN SARAN.}

\section{A. Simpulan}

1. Proses litigasi yang selama ini dilakukan, seluruh proses hukum yang akan dilalui oleh perempuan pelaku tindak pidana diserahkan seluruhnya kepada penasihat hukum. Model litigasi selama ini belum memberikan kesadaran terhadap perempuan pelaku tindak pidana (korban termarginalkan). Nasib korban seluruhnya tergantung pada penasihat hukum. Pengetahuan terhadap hak-hak korban sebagai subjek hukum tidak ditumbuhkan, karena tidak diberikan pemahaman dan kesadaran menggunakan hak-haknya. Dari keterangan yang disampaikan oleh para warga binaan wanita Lembaga Pemasyarakatan menyatakan bahwa umumnya proses pendampingan yang dilakukan hanya terbatas pada proses pendampingan di dalam pengadilan saja. Proses pendampingan yang dilakukan tidak dimulai semenjak mereka ditahan dan tidak dilakukan semenjak mereka akan menjalankan proses hukum acara, sehingga pembelaan yang diharapkan dapat dilakukan oleh penasihat hukum sebagai tugas dari lembaga bantuan hukum tidak terlaksana secara maksimal. Dengan demikian, perlu dicari model alternatif pendampingan yang dapat memberdayakan perempuan pelaku tindak pidana dalam kasus kekerasan rumah tangga selain yang selama ini dilakukan melalui litigasi konvensional. Untuk solusi tersebut, alternatif model advokasi mandiri perlu diuji cobakan.

Copyright $\odot$ 2015, LITIGASI, p-ISSN: 0853-7100; e-ISSN: 2442-2274 
Available online at: http://ejournal.unpas.ac.id/index.php/litigasi

Litigasi, Vol. 16(1), 2015, 2658-2740

DOI: http://dx.doi.org/10.23969/litigasi.v16i1.51

2. Proses pendampingan melalui cara litigasi konvensional yang sudah berjalan faktanya banyak memiliki kelemahan, dan sering tidak dipergunakan oleh perempuan pelaku tindak pidana kasus KDRT. Dengan demikian, alternatif pendampingan bagi perempuan pelaku tindak pidana kekerasan dalam rumah tangga, dari model advokasi konvensional yang sekarang berjalan berdasarkan sistem hukum acara yang berlaku di Indonesia, baik hukum acara pidana maupun hukum acara perdata, dapat diubah menjadi model advokasi mandiri sebagai bagian dari pembaharuan proses peradilan di Indonesia. Pendampingan dapat dilakukan bukan hanya oleh profesi hukum yang beracara dalam proses peradilan, namun dapat dilakukan oleh para ahli hukum (dosen, pendidik, mahasiswa hukum, dan sebagainya) yang dilakukan diluar proses peradilan. Pendampingan dilakukan untuk memberikan pemahaman kepada perempuan pelaku tindak pidana KDRT tentang hakhaknya, pemahaman terhadap kasus yang sedang dihadapi, dan pemahaman terhadap kedudukan hukum dan posisinya, selanjutnya mereka dibekali pula pemahaman proses beracara. Dalam rangka mengefektifkan model litigasi mandiri ini, pendampingn dan klien dibekali juga dengan modul (atau buku ajar) yang dapat membantu mempermudah pemahaman terhadap mereka. Kontruksi model litigasi mandiri sebagai alternatif advokasi terhadap perempuan pelaku tindak pidana dengan konsentrasi pada kasus kekerasan dalam rumah tangga, 
Available online at: http://ejournal.unpas.ac.id/index.php/litigasi

Litigasi, Vol. 16(1), 2015, 2658-2740

DOI: http://dx.doi.org/10.23969/litigasi.v16i1.51

yaitu dengan cara mendampingi perempuan sebagai pelaku selama menjalani proses hukum, tetapi tidak secara litigasi (tidak mendampingi di pengadilan layaknya penasehat hukum), melainkan memberikan pengetahuan hukum secara jelas terkait dengan persoalan hukumnya, sehingga diharapkan akan menumbuh kembangkan kesadaran hukum terhadap perempuan tindak pidana yang termarginalkan dalam kasus kekerasan dalam rumah tangga, dan diharapkan dari pendampingan tersebut perempuan pelaku tindak pidana dapat menghadapi sendiri proses hukum tersebut dengan berbekal ilmu hukum yang telah dipahaminya. Dengan model pendampingan ini, akan memberikan pilihan alternatif penyelesaian perkara hukum bagi perempuan pelaku tindak pidana, apakah akan menggunakan proses litigasi yang selama ini berjalan (konvensional) ataukah akan menggunakan proses pendampingan dengan model advokasi mandiri, sehingga pelaku akan menghadapi sendiri proses hukum dengan berbekal ilmu dan pengetahuan yang diperoleh dalam proses pendampingan. Urgensi dari penelitian ini dapat mendobrak model litigasi yang selama dilakukan di dalam sistem peradilan di Indonesia (model peradilan konvensional) yang mendominasi dan kurang memberikan ruang gerak bagi kaum perempuan, juga tidak memberikan keleluasaan untuk mengapresiasikan hak-hak yang terkait dengan perlindungan hukumnya. Dengan dibuatnya buku ajar dalam bentuk modul yang akan menjadi pedoman bagi para perempuan sebagai pelaku 
Available online at: http://ejournal.unpas.ac.id/index.php/litigasi

Litigasi, Vol. 16(1), 2015, 2658-2740

DOI: http://dx.doi.org/10.23969/litigasi.v16i1.51

tindak pidana kekerasan dalam rumah tangga untuk dapat mengadvokasi dirinya sendiri pada saat menghadapi proses peradilan, sehingga pelaku dapat memahami kedudukan hukumnya, dan dapat membela dirinya sendiri, sehingga dengan model advokasi mandiri ini dapat meningkatkan pemberdayaan perempuan akan hak-hak dan kedudukan hukumnya. Bagi pemerintah model advokasi mandiri ini menjadi alternatif baru di dalam proses peradilan, sehingga dapat dijadikan pertimbangan dan upaya untuk dilakukannya pembaharuan proses peradilan.

\section{B. Saran}

1. Bagi pembuat undang-undang diharapkan dapat memproses terbentuknya peraturan yang mengatur tentang advokasi mandiri sebagai bagian dari pembaharuan proses peradilan di Indonesia.

2. Diharapkan bagi penegak hukum, advokasi mandiri ini menjadi alternatif dalam memberikan pendampingan bagi pelaku tindak pidana, khususnya perempuan pelaku tindak pidana.

Copyright $\odot$ 2015, LITIGASI, p-ISSN: 0853-7100; e-ISSN: 2442-2274 


\section{DAFTAR PUSTAKA}

Ali Budiardjo dan Nugroho Reksodiputro (kerja sama dengan Mochtar, Karuwin \& Komar). 2002. Reformasi Hukum di Indonesia Hasil Studi Perkembangan Hukum - Proyek Bank Dunia. Jakarta: Cyber Consult.

Al, Wisnubroto dan G, Widiartana. 2005. Pembaharuan Hukum Acara Pidana. Bandung: Citra Aditya Bakti.

Barda Nawawi Arif. 1998. Beberapa Aspek Kebijakan Penegakan Dan Penegakkan Hukum Pidana. Bandung: Citra Aditya Bhakti.

Darwin Muhadjir dan Tukiran ed. 2001. Menggugat Budaya Patriarki. Yogyakarta: Pusat Penelitian Kependudukan dan Ford Foudation.

Darwin Muhadjir. 1990. Negara dan Perempuan: Reorientasi Kebijakan Publik. Yogyakarta: Grha Guru.

Departemen Pendidikan dan Kebudayaan. 2005. Kamus Besar Bahasa Indonesia. Jakarta: Balai Pustaka.

Edriana Noerdin. 2006. Potret Kemiskinan Perempuan. Jakarta: Women Research Institute (WRI).

Hakim Rahmat. 2000. Hukum Perkawinan Islam. Bandung: CV Pustaka Setia. 
Herkutanto. 2000. Kekerasan Terhadap Perempuan dan Sistem Hukum Pidana. Pendekatan dari Sudut Pandang kedokteran dalam Buku Penghapusan Diskriminasi terhadap Perempuan. Bandung: Alumni.

Heru Nugroho. 2001. Negara, Pasar, dan Keadilan Sosial. Yogyakarta: Pustaka Pelajar.

Irianto Sulistyowati (editor). 2006. Perempuan dan Hukum. Jakarta: Yayasan Obor Indonesia.

2005. Perempuan Diantara Berbagai Pilihan Hukum. Jakarta: Yayasan Obor Indonesia.

Kent Roach. 1998. Due Process and Victim's Right ; The new Law and Politic's of Criminal Justice. London: University of Toronto Press. Toronto Buffalo.

Koentjaraningrat. 2002. Kebudayaan Mentalitas dan Pembangunan. Jakarta: Gramedia.

Komnas Perempuan. 2008. Refleksi 10 Tahun Reformasi. Jakarta: Komnas Perempuan.

Marlina. 2009. Peradilan Pidana Anak di Indonesia. 
Available online at: http://ejournal.unpas.ac.id/index.php/litigasi

Litigasi, Vol. 16(1), 2015, 2658-2740

DOI: http://dx.doi.org/10.23969/litigasi.v16i1.51

Marjono Reksodiputro. 1997. Kriminologi dan Sistem Peradilan Pidana (kumpulan

Karangan Buku Ke-2). Jakarta: Pusat Pelayanan Keadilan dan Pengabdian Hukum Lembaga Kriminologi UI.

. 1999. Hak Asasi manusia Dalam Sitem Peradilan Pidana (kumpulan

Karangan Buku ke -3). Jakarta: Pusat Pelayanan Keadilan dan Pengabdian Hukum Lembaga Kriminologi UI.

. 1997. Pe mbaharuan Hukum Pidana (kumpulan Karangan Buku ke -

4). Jakarta: Pusat Pelayanan Keadilan dan Pengabdian Hukum Lembaga Kriminologi UI.

- 1997. Bunga Rampai Permasalahan dalam Sistem Peradilan Pidana

(kumpulan Karangan Buku ke -5). Jakarta: Pusat Pelayanan Keadilan dan Pengabdian Hukum Lembaga Kriminologi UI.

Monty P, Satiadarma. 2001. Menyikapi Perselingkuhan. Jakarta: Pustaka Populer Obor

Mufidah Ch. 2004. Paradigma Gender, Malang: Bayumedia Publishing.

Muladi. 2002. HAM, Politik dan Sistem Peradilan Pidana. Semarang: Badan Penerbit UNDIP.

Nani Soedarsono. 2000. Pembangunan Berbasis Rakyat. Jakarta: Melati Bhakti Pertiwi.

Copyright @ 9 2015, LITIGASI, p-ISSN: 0853-7100; e-ISSN: 2442-2274 
Available online at: http://ejournal.unpas.ac.id/index.php/litigasi

Litigasi, Vol. 16(1), 2015, 2658-2740

DOI: http://dx.doi.org/10.23969/litigasi.v16i1.51

Parman Soeparman. 2007. Pengaturan Hak Mengajukan Upaya Hukum Peninjauan Kembali Dalam Perkara Pidana Bagi Korban Kejahatan. Bandung: PT. Refika Aditama.

Poerwandari Kristi. 2000. Kekerasan terhadap Perempuan Tinjuan Psikologis Dalam Buku Penghapusan Diskriminasi Terhadap Perempuan. Bandung: Alumni.

Prayudi Guse. 2008. Berbagai Aspek Tindak Pidana Kekerasan Dalam Rumah Tangga. Yogyakarta: Markid Press.

Rita Serena Kolibonso. 2002. Kejahatan Itu Bernama Kekerasan Dalam Rumah Tangga.

Ritu R, Sharma. 2004. Pengantar Advokasi Panduan dan Latihan, Alih Bahasa : P. Soemitro. Jakarta: Yayasan Obor Indonesia.

Romli Atmasasmita. 2010. Globalisasi dan Kejahatan Bisnis. Jakarta: Kencana Prenada Media Group.

Romany Sihite. 2007. Perempuan, Kesetaraan, Keadilan. Jakarta: PT. Rajagrafindo.

Zaitunah Subhan. 2004. Kekerasan terhadap Perempuan, Yogyakarta: Pustaka Pesantren.

Copyright @ 9 2015, LITIGASI, p-ISSN: 0853-7100; e-ISSN: 2442-2274 


\section{PERATURAN PERUNDANG-UNDANGAN}

Undang Undang Dasar 1945.

Undang-Undang Nomor 1 Tahun 1974 Tentang Perkawinan

Undang-Undang Nomor 7 tahun 1984 tentang Pengesahan Konvensi tentang Penghapusan Segala Bentuk Diskriminasi Terhadap Perempuan (Lembaran Negara RI Tahun 1984 Nomor 29 Tambahan Lembaran Negara RI Nomor 3277.

Undang-Undang Nomor 23 tahun 2004 tentang Penghapusan Kekerasan Dalam Rumah Tangga (KDRT) Lembaran Negara RI Tahun 2004 Nomor 95.

\section{SUMBER LAIN}

1997. Bunga Rampai Permasalahan dalam Sistem Peradilan Pidana. (kumpulan Karangan Buku ke -5). Jakarta: Pusat Pelayanan Keadilan dan Pengabdian Hukum Lembaga Kriminologi UI.

Fathiyah Wardah-Komnas Perempuan: 60\% Korban KDRT hadapi kriminalisasi (Undang-Undang penghapusan KDRT kerap digunakan aparat penegak hukum untuk mengkriminalkan perempuan korban.). Koran Berita Indonesia. Selasa. 10 Juni 2014.

Copyright @ C 2015, LITIGASI, p-ISSN: 0853-7100; e-ISSN: 2442-2274 
Harkristuti Harkrisnowo. Menyimak RUNDANG-UNDANG Perlindungan Terhadap Korban Kekerasan Dalam Rumah Tangga. Jurnal Legislasi Indonesia. Volume I. Nomor 1. Juli 2004.

Irsan Koesparmono. Hak Asasi Manusia Dikaitkan Dengan Penegakan Hukum. Makalah. Disampaikan pada Seminar tentang Hak Asasi Manusia Dikaitkandenagn Penegakan Hukum, diselenggarakan oleh Kelompok Kerja Convention Watch, Program Studi Kajian Wanita. Program Pasca Sarjana UI dan Universitas Atmajaya. tanggal 5 Mei 1998.

Muchsin. Peranan Putusan Hakim Pada Kekerasan Dalam Rumah Tangga. dalam Varia Peradilan Majalah Hukum. Tahun Ke XXII. Nomor 260. Juli 2007.

Parman Soeparman. Kepentingan Korban Tindak Pidana Dilihat Dari Sudut Victimologi. dalam Varia Peradilan Majalah Hukum. Tahun Ke XXII. Nomor 260. Juli 2007.

Nur Rochaeti. Pemahaman Kritis Tindak Pidana Kekerasan terhadap Perempuan. Majalah Masalah-masalah Hukum. FH Undip. Edisi W Juli-September 1999.

Suharyono AR,. Rancangan KUHAP Dalam Prospek Penegakan Hukum di Indonesia. Dalam Jurnal Legislasi Indonesia/ Indonesian Journal of Legislation. Volume 7 Nomor 3. Oktober 2010. 
Available online at: http://ejournal.unpas.ac.id/index.php/litigasi

Litigasi, Vol. 16(1), 2015, 2658-2740

DOI: http://dx.doi.org/10.23969/litigasi.v16i1.51

Ruswiyati Suryasaputra. Kebijakan dan Program Perlindungan Perempuan Dari Tindak

Kekerasan. Makalah Kegiatan Kampanye Hak Asasi Perempuan dalam

Rangka Peringatan Hari HAM se-Dunia 10 Desember 2005. Semarang. 30

September 2005.

Copyright $\odot$ 2015, LITIGASI, p-ISSN: 0853-7100; e-ISSN: 2442-2274 